UDC $669.186 .2: 666.924 .1: 669.186 .554 .62: 669.186 .555 .85$ 論 文

\title{
$\mathrm{CaO}$ 坩堝による溶鉄と溶融鉄合金のカルシウム脱酸
} およびアルミニウム脱硫*

\author{
音谷 登平** 形浦 安治**. 出川通***
}

\section{Calcium Deoxidation and Aluminium Desulphurization of Liquid Iron and Liquid Iron Alloy with a Lime Crucible}

Tohei Ototani, Yasuzi Kataura, and Toru Degawa

\section{Synopsis :}

Using a lime crucible and an induction furnace in vacuum as well as at pressure, a study was made to clarify the deoxidation and the desulphurization processes of liquid iron and iron-base alloys by iron clad calcium or aluminium alone.

The experimental results are summarized as follows.

(1) Calcium addition to liquid iron in a magnesia or alumina crucible greatly influenced the rate of deoxidation and the deoxidizing power owing to the reaction of the crucible material with calcium.

(2) The $\mathrm{CaO}-\mathrm{FeO}$ oxide which was formed for liquid iron in a lime crucible immediately after the calcium addition seemed to grow and to be separated from the melt with time.

(3) At $1600^{\circ} \mathrm{C}$ in $1 \mathrm{~atm}$ argon, the concentration of calcium dissolved in liquid iron was estimated to be $0.024 \mathrm{wt}$ pct. The equilibrium constants were calculated as follows. $\log K_{\mathrm{ca}}=\log a_{\mathrm{ca}} \cdot a_{\mathrm{o}}=-8 \cdot 23$ and $K_{\mathrm{ca}}^{\prime}=[\% \mathrm{Ca}] \times[\% \mathrm{O}]=2 \cdot 16 \times 10^{-6}$.

(4) It is presumed that the aluminium desulphurization of liquid iron in a lime crucible is caused by the formation of highly basic reaction product layer such as $3 \mathrm{CaO} \cdot \mathrm{Al}_{2} \mathrm{O}_{3}$ on the surface of the crucible.

\section{1. 緒言}

金属 $\mathrm{Ca}$ は化学的に活性な元素であり，蒸気圧が高い ことまた溶鉄に対して溶解度が小さいことなどで，鉄鋼 に関する研究の多くは Ca を含む複合合金を用いてなさ れてきたし, 最近にみられる $\mathrm{Ca}$ 単独脱酸に関する研究 も特殊な条件下でなされている1)2

本研究においては自家製 $\mathrm{CaO}$ 坩堝を用い，溶鉄なら びに溶融鉄合金に対して金属 $\mathrm{Ca}$ を実用的に近い方法で 添加するように工夫し, 各種溶湯における脱酸挙動, 残 留 $\mathrm{Ca}$ の調査, 介在物の観察などを通じて $\mathrm{Ca}$ にる脱 酸過程の解析および脱酸力の評洒を行なわんとした。ま た坩堝材に用いた $\mathrm{CaO}$ は, 高温で熱力学的に安定度が 高くかつ高塩基性を有するため, 溶鉄の脱硫にも好条件 であることは容易に推定できることである．したがつて
$\mathrm{CaO}$ 坩堝による溶鉄に対し，種々の脱酸添加㓢のうち 特に $\mathrm{Al}$ 添加により, 脱酸に附随して認められた脱硫作 用に関しても $2 ， 3$ の検討を試み゙た.

\section{2. 実倹方法}

\section{1 鉄被 $\mathrm{Ca}$ クラッド材および $\mathrm{CaO}$ 坩堷の作製}

シリコニット炉を用い，粒状金属 Ca $(>99 \%)$ を鋼 坩堝中 Ar 雾囲気下で溶解し $20 \mathrm{~mm}$ 丸金型に鋳込んだ. この鋳塊を17 mm丸までタップ鍛造後配管用鋼管 (SGP, 3/8B) に㨂入し, 外径 $10 \mathrm{~mm}$ 丸まで鋁圧して Fe と $\mathrm{Ca}$ の重量比が 8:2 のクラッド材を作製した. その形状を Fig. 1 (a) に示したが, 使用目的量に応じて切断し, 一端を封じて溶鉄中への添加に供した.

溶解には主として Fig. 1（b）に示した寸法の自家製 $\mathrm{CaO}$ 坩堝を用い, このほか市販の $\mathrm{Al}_{2} \mathrm{O}_{3}$ または $\mathrm{MgO}$

* 昭和 49 年 4 月本会講演大会にて一部発表 昭和 49 年 12 月 3 日受付 (Received Dec. 3, 1974)

** 東北大学金属材料研究所工博 (The Research Institute for Iron, Steel and Other Metals, Tohoku University, Katahira-chô, Sendai 980)

*** 東北大学大学院（現在：三井造船玉野研究所）(Mitsui Shipbuilding and Engineering Co., Ltd.) 


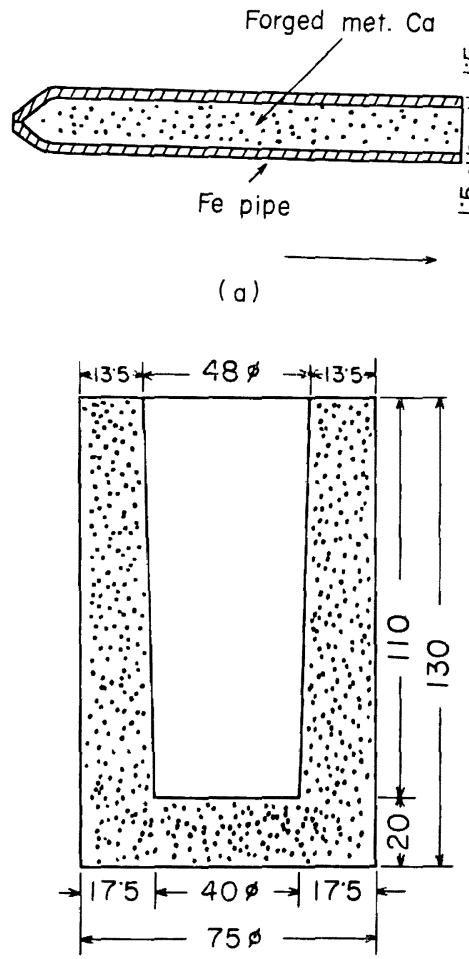

(b)

Fig. 1. (a) Dimension of iron clad calcium.(mm) Arrow shows the direction of the addition to the melt.

(b) Dimension of lime crucible. ( $\mathrm{mm}$ )

坩堝 $(63 \times 53 \times 160 \mathrm{~mm})$ をも使用した。 またいずれの 場合も外坩堝には $85 \times 75 \times 160 \mathrm{~mm}$ のアルミナ質のもの を用いた。 $\mathrm{CaO}$ 坩堝の作製には一級試薬の酸化カルシ ウムを原料とし，20^ッシュ程度に粉哗後酶酸を $5 \%$ 含 むメチルアルコールを適量加えてよく混合し，外坩堝内

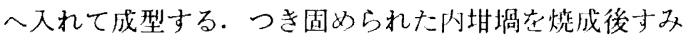
やかに使用した。

\section{$2 \cdot 2$ 溶解方法および試料の作製}

脱酸実験について：溶解に際しては出力 $15 \mathrm{~kW}, 70 \mathrm{kHz}$ の真空兼加圧方式の高周波誘導溶解炬を用いた，溶解原 料以は電解鉄（>99.9\%），電解ニッケル（>99.98\%） および電解クローム $(>99 \cdot 2 \%)$ などを用い，溶鉄，3〜 $30 \% \mathrm{Ni}$ および 10〜30\% Cr の溶融鉄合金の $500 \mathrm{~g}$ また は $800 \mathrm{~g}$ を溶解量とした。脱酸戍の添加にあたつては， 真空中で溶落後約 $10 \mathrm{~min}$ 間 $10^{-4}$ Torr 程度で真空処 理をした㹂拌浴に対し， $1600^{\circ} \mathrm{C}$ Ar 1 父圧下で $2 \mathrm{~mm}$

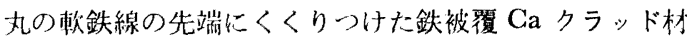

を浴中に㨂入した.

脱硫実験について：脱酸実験と同梯な溶解方法で $\mathrm{CaO}$ 坩堝を用い，一級試薬の FeS で初期硫黄量を 0.008〜 $0.14 \%$ まで調整した主として $500 \mathrm{~g}$ の電解鉄溶湯に対 し, Ar 1 気圧下で $\mathrm{Si}, \mathrm{Al}, \mathrm{Ca}$ または Ce定添加郕に 選んだ.

このような脱酸または脱硫実験において脱酸元素を添 加後, 所定時間ごとに内径 $5 \mathrm{~mm}$ 丸の不透明石英管を用 い，約 $30 \mathrm{~g}$ の溶鉄を吸引採取して水中に急冷した。試 料採取中は溶湯の温度を $\mathrm{Pt} / \mathrm{Rh} 30 \%-\mathrm{Pt} / \mathrm{Rh} 6 \%$ 熱電対 および光高温温度計で観測し $1600^{\circ} \mathrm{C} \pm 10^{\circ} \mathrm{C}$ に保持し た. $5 \mathrm{~mm}$ 丸の吸引採取試料よりガス分析ならびに組成 分析試料を削り出し，残部につき光学顕微鏡および $\mathrm{P}$ MA による非金属介在物の観察ならびに同定を行なつ た. 分析方法については, $\mathrm{O}_{2}$ 法不活性ガス溶融電量滴 定法， $\mathrm{S}$ は燃焼容量法また $\mathrm{Al}, \mathrm{Ca}, \mathrm{Mg}$ 等は原子吸光 法によつた、なお脱硫実験で使用前後の $\mathrm{CaO}$ 坩堝壁よ り削りとつた粉末をX線回折法または化学分析によつて 調査した.

\section{3. 実 験 結 果}

\section{1 溶鉄の $\mathrm{Ca}$ 脱酸におよぼす添加方法の影響}

$\mathrm{CaO}$ 坩佩を用いて電解鉄を溶解し, $\mathrm{FeS}$ を $0 \cdot 12 \%$ 添 加した溶鉄を脱酸せずに $\mathrm{Ar} 1$ 父圧下で $1600^{\circ} \mathrm{C} \pm 10^{\circ} \mathrm{C}$ に保持しながら試料の吸引採取を $10 \mathrm{~min}$ 間続けた。こ の場合 Fig. 2 に示したごとく，本実験条件では保持時 間で溶鉄中の $[\mathrm{O}]$ および [S] の変化は認められなか つた. 次に Ar 1 匃压下で $1600^{\circ} \mathrm{C}$ の溶鉄に-4〜+30 メッシュの粘状金属 $\mathrm{Ca}$ を $0.5 \%$ 表面添加した場合と， 鉄被覆 $\mathrm{Ca}$ クラッド材 $(0.5 \% \mathrm{Ca}$ 相当) を浴中に添加 した場合の脱酸挙動の比較を脱酸率 $\left\{\left([\mathrm{O}]_{0}-[\mathrm{O}]_{t}\right) /\right.$ $\left.[\mathrm{O}]_{0}\right\} \times 100$ で示したのが Fig. 3 である. [O $]_{0}$ は初期

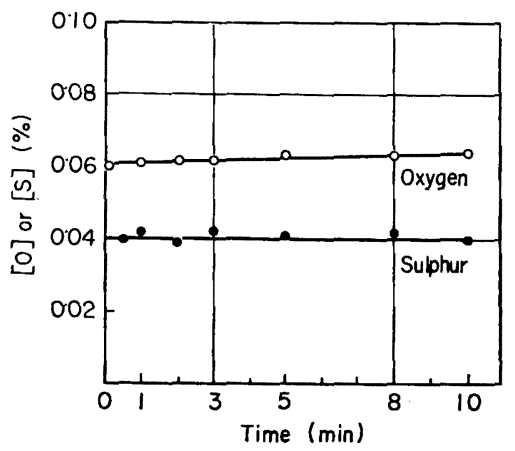

Fig. 2. Change in oxygen and sulphur contents of liquid iron with time. 


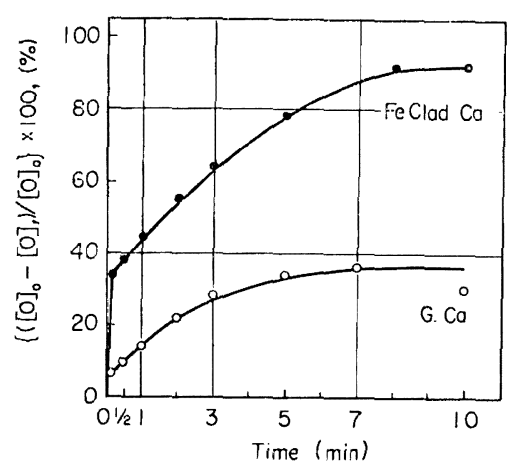

Fig. 3. Comparison of deoxidation degrees in liquid iron after adding $0.5 \%$ granular calcium (G. Ca) and iron clad calcium. $[\mathrm{O}]_{0}$ : Initial oxygen

$[\mathrm{O}]_{t}$ : Oxygen after $t \mathrm{~min}$

の全酸素量, $[\mathrm{O}]_{t}$ は脱酸後 $t \min$ の全酸素量である. 粒状の金属 $\mathrm{Ca}$ 表面添加した場合より鉄浴中へクラッ ド材として Ca を添加した場合には，脱酸作用が効果的 であることが判明した.したがつて以下の実験は主とし て鉄被覆 $\mathrm{Ca}$ クラッド材（以下単に $\mathrm{Ca}$ と記す）を用い て金属 $\mathrm{Ca}$ の添加を行なつた。

\section{2 溶鉄の $\mathrm{Ca}$ 脱酸におよぼす坩堝材質の影響}

$\mathrm{Ca}$ のような酸素と親和力の強い元素を脱酸戍に用い る場合，溶鉄への溶解度が小さくとも用いる坩堝材との 反応が予測され，その反応によつて脱酸速度や到達酸素 值に影響をおよぼすことが考えられる。そこで $\mathrm{CaO}$ 坩 堝以外に市販の $\mathrm{Al}_{2} \mathrm{O}_{3}$ や $\mathrm{MgO}$ 坩堝を比較材に選び， Caを 0.5\% 添加してそれぞれの脱酸挙動を調べた.Fig. 4 は坩堝材質による経時变化と [O] との関係を片対数 で表示したものである. [O] 間的に減少し，その後ほほ直線的に低下した後一定とな るが，脱酸限については $\mathrm{Al}_{2} \mathrm{O}_{3}$ 坩堝の場合に最も低くつ いで $\mathrm{CaO}, \mathrm{MgO}$ 坩墧の順に高くなつている. この場合 $\mathrm{Ca}$ 添加 $10 \mathrm{sec}$ 以後に打いては時間 $t$ と全酸素量との対 数 $\ln [\mathrm{O}]$ の間には直線関係が成立していることにより 次式の関係が得られる.

$$
[\mathrm{O}]_{t}=[\mathrm{O}]_{10} \prime \exp (-k t) \text {. }
$$

$k$ : 脱酸速度定数, $t: \mathrm{Ca}$ 添加後の経時時間 ( $\mathrm{min}$ ) $[\mathrm{O}]_{t}: t \min$ 後の全酸素量 $(\mathrm{wt} \%),[\mathrm{O}]_{10}{ }^{\prime \prime}: \mathrm{Ca}$ 添 加 $10 \mathrm{sec}$ 後の酸素量 $(w t \%)$

ここで脱酸の速度定数 $k$ を見積つたところ Table 1 に 示したとおりであり，坩城材質により差のあることが判 明した.このように脱酸挙動に著しい差が認められるこ とは，溶鉄温度における诗堝材の Ca による還元反応が

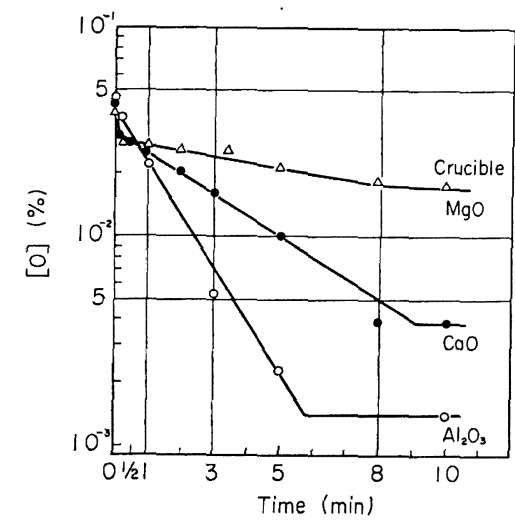

Fig. 4. Change in oxygen content of liquid iron for various crucibles after adding $0.5 \%$ calcium.

Table 1. Effect of crucible materials and the amount of calcium addition on the rate of deoxidation.

\begin{tabular}{l|c|c|c|c}
\hline Crucible & $\begin{array}{c}\mathrm{Ca} \text { add. } \\
(\%)\end{array}$ & $\begin{array}{c}{[\mathrm{O}]} \\
10 \mathrm{sec}\end{array}$ & $\begin{array}{c}\text { Range of } \\
\text { time (sec) }\end{array}$ & $k$ \\
\hline $\mathrm{MgO}$ & 0.5 & 0.029 & $10-480$ & 0.06 \\
$\mathrm{CaO}$ & 0.5 & 0.030 & $10-540$ & 0.23 \\
$\mathrm{Al}_{2} \mathrm{O}_{3}$ & 0.5 & 0.037 & $10-360$ & 1.06 \\
\hline & 0.1 & 0.038 & $10-30$ & 0.053 \\
$\mathrm{CaO}$ & 0.3 & 0.028 & $10-420$ & 0.08 \\
& 0.5 & 0.030 & $10-540$ & 0.23 \\
& 1.0 & 0.023 & $10-600$ & 0.24 \\
\hline
\end{tabular}

考えられる.すなわち各酸化物の安定度の度合は, $J G^{\circ}$ $\left(=R T \ln P_{\mathrm{O}_{2}}\right.$ ) -温度線图から $\mathrm{MgO}: \Delta G^{\circ}{ }^{\circ} 600^{\circ} \mathrm{C}=-164$ kcal, $\mathrm{Al}_{2} \mathrm{O}_{3}: \Delta G^{\circ} 1600^{\circ} \mathrm{C}=-170 \mathrm{kcal}, \quad \mathrm{CaO}: \Delta G_{1} 600^{\circ} \mathrm{C}$ $=-203 \mathrm{kcal}$ 程度であると見積られる. したがつて

$$
\begin{aligned}
& \mathrm{MgO}+\mathrm{Ca}_{(v)} \text { または } \underline{\mathrm{Ca} \rightarrow \mathrm{Mg}(v)}+\mathrm{CaO} \cdots \cdots(2) \\
& \mathrm{Al}_{2} \mathrm{O}_{3}+3 \mathrm{Ca}_{(v)} \text { または } 3 \underline{\mathrm{Ca}} \rightarrow 2 \underline{\mathrm{Al}}+3 \mathrm{CaO} \cdots \cdots(3) \\
& 2 \underline{\mathrm{Al}}+3 \underline{\mathrm{O}} \rightarrow \mathrm{Al}_{2} \mathrm{O}_{3} \cdots \cdots \cdots \cdots \cdots \cdots \cdots \cdots \cdots \cdots \cdots \cdots(4)
\end{aligned}
$$

(2)，（3）の反応は右人進むことが予想される.また $\mathrm{Al}_{2} \mathrm{O}_{3}$ 㘿堝を使用した場合には式 (3)によつて溶出した Al が溶鉄中のOと結びつき式 (4)のごとく脱酸に奇与 することが十分に考えられる. 一方 $\mathrm{MgO}$ 坩佩を使用し た場合は, 式(2)により還元で生成する $\mathrm{Mg}_{(v)}$ の蒸気 压は $1600^{\circ} \mathrm{C}$ で 23 気圧程度と著しく高く, かつ溶解 度も小さいことから $\mathrm{Mg}_{(v)}+\underline{\mathrm{O}} \rightarrow \mathrm{MgO}$ の脱酸反応はほ とんど起こり得ず, 添加 $\mathrm{Ca}$ の一部は単に $\mathrm{MgO}$ 坩佩壁 の還元に消耗されたにすぎず，このため脱酸限も高かつ たゆえんと考えられる．この点を確認するためCa の添 加前後において溶鉄中に残存した $[\mathrm{Al}],[\mathrm{Mg}]$ ならび 


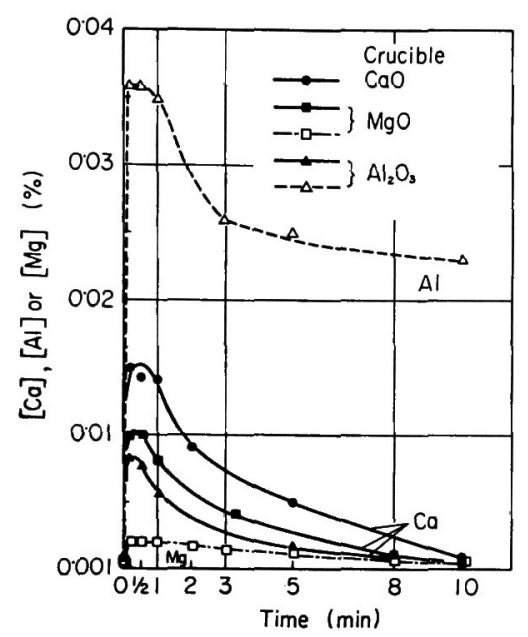

Fig. 5. Changes in residual aluminium, calcium and magnesium of liquid iron for various crucibles after adding $0.5 \%$ calcium.

に [Ca] の変化を経時变化とともに示したのが Fig. 5 である. $\mathrm{Al}_{2} \mathrm{O}_{3}$ 坩堝を使用の場合， $\mathrm{Ca}$ 添加前に溶鉄中 の $\mathrm{Al}$ は不純物として 0.001\% 存在していたが， Ca 添 加 $10 \mathrm{sec}$ 後には $0.036 \%$ 認められた事実より, $\mathrm{Al}_{2} \mathrm{O}_{3}$ 坩 堝の還元は Ca 添加直後に起こり, 時間の経過とともに みられる [Al] の減少は脱酸反応に関与したためと考元 られた. 一方 $\mathrm{MgO}$ 坩堝の還元によると推測される $[\mathrm{Mg}]$ の残留量は， $\mathrm{Ca}$ 添加初期においてもその高蒸気压と低 溶解度のため僅か $10 \mathrm{ppm}$ の増加が認められたにすぎな い. [Ca] の残留量については $\mathbf{C a}$ の添加後 10〜30 sec 間に最大値を示し, $\mathrm{CaO}$ 坩堝の場合に 0.015\% と最も 高く, ついで $\mathrm{MgO}, \mathrm{Al}_{2} \mathrm{O}_{3}$ 坩堝の順に低い值を示した。 後二者の場合には添加 $\mathrm{Ca}$ が坩堝材との反心で消耗され た結果によるものと推察される。しかしながら $10 \mathrm{~min}$ 後の [Ca] はいずれの場合も $10 \mathrm{ppm}$ 程度の残留量を示 したにすぎなかつた.

\section{3 脱酸生成物について}

$\mathrm{Al}_{2} \mathrm{O}_{3}$ 坩堝での $\mathrm{Ca}$ 添加実験では, $\mathrm{Ca}$ 添加後 1 min 以内に溶湯より採取した試料中には球状介在物以外に群 落状のものが多くみられたが $3 \mathrm{~min}$ 以後においては観察 されずこれらの介在物は系外へ浮上分離したものと考え られる. Ca 添加 $1 \mathrm{~min}$ 後の試料に認められた群落状介 在物につき EPMA で定性分析を行なつた結果をPhoto. 1 に示した. これょり介在物は $\mathrm{Ca}$ と $\mathrm{Al}$ を含む $\mathrm{CaO}$ $-\mathrm{Al}_{2} \mathrm{O}_{3}$ 系介在物であることが確認され，またほかに観 察された球状介在物についても同様な組成であることが 判明した. このことは $\mathrm{Al}_{2} \mathrm{O}_{3}$ 时堝から $\mathrm{Ca}$ の還元作用

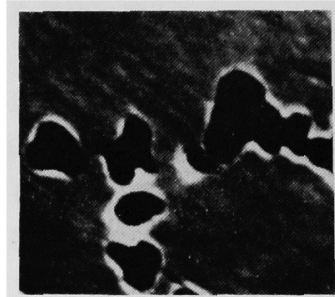

S.E.

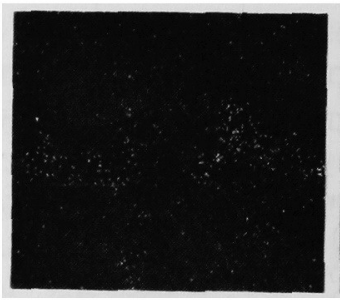

O

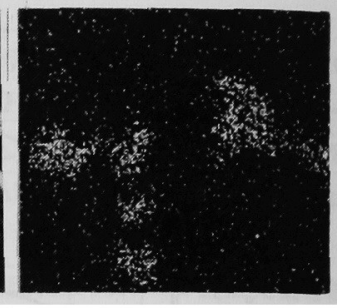

$\mathrm{Ca}$

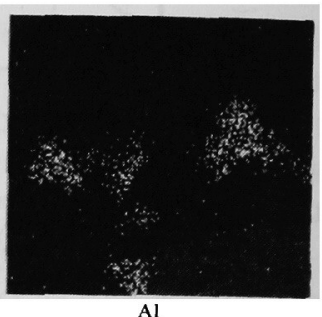

Al
Photo. 1. Electron beam scanning images of oxide inclusions in pen sampling taken from liquid iron in an alumina crucible $1 \mathrm{~min}$ after calcium addition. $\times 3000(5 / 6)$

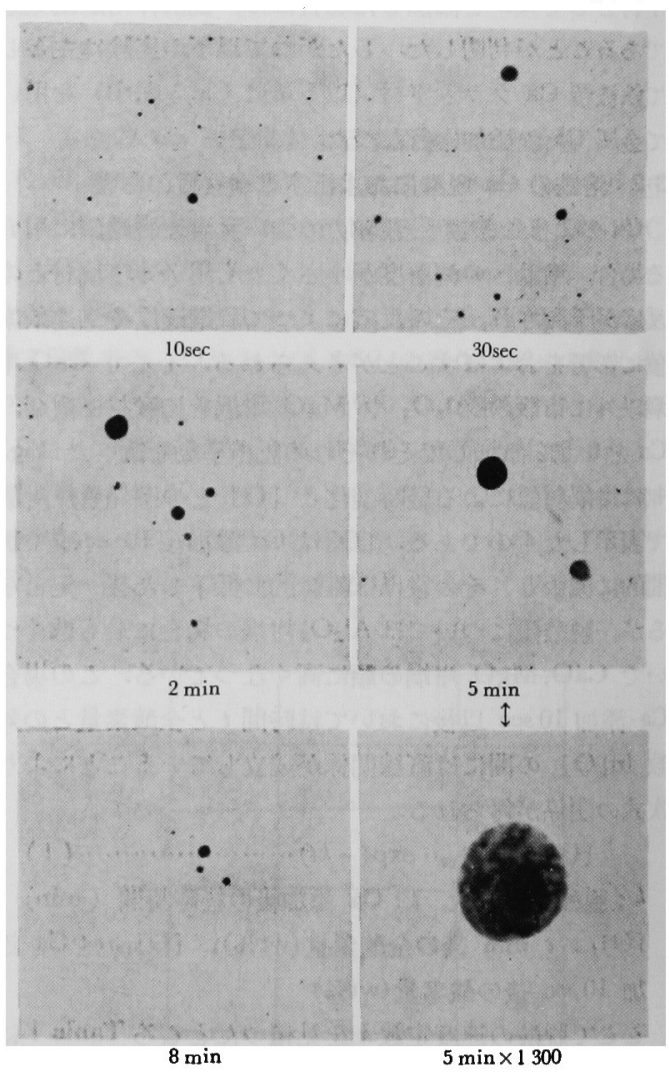

Photo. 2. Growth of oxide inclusions in liquid iron with holding time after $0.5 \%$ calcium addition. $\times 360(9 / 10)$ 
によつて一度溶出した $\underline{\mathrm{Al}}$ が $\mathrm{Al}_{2} \mathrm{O}_{3}$ を主成分とする $\mathrm{CaO}-\mathrm{Al}_{2} \mathrm{O}_{3}$ 系の群落状介在物を生成し, 比較的すみや

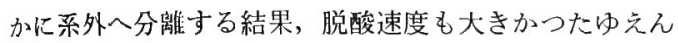
と考元られる. Photo. 2 は $\mathrm{CaO}$ 坥佩で $\mathrm{Ca}$ の $0.5 \%$ 添 加を行なつた場合, 経時時間による介在物の变化を示し たものである. Ca 脱酸後 $1 \mathrm{~min}$ 以内にみとめられた 2 $\mu$ 程度の微細に分散した球状介在物はしだいに成長し 5 $\min$ 後には $12 \mu$ 程度に達し,その後このような大きい 介在物は観察されなくなる.かりにこれらの介在物組成 がすべて $\mathrm{CaO}$ 単体であるとすると, $\mathrm{CaO}$ 単体では融 点が $2572^{\circ} \mathrm{C}$ ときわめて高く, 本実験結果のような成辰 は起こり得ないと考えられる。 $\mathrm{CaO}-\mathrm{FeO} 2$ 元状態闵か らも明らかなごとく, 溶鉄温度で $\mathrm{CaO}$ は $\mathrm{FeO}$ を固溶し 得るため $\mathrm{CaO}-\mathrm{FeO}$ 系介在物のごとき低融点の介在物 が生成されるものと推定される. 一例として Ca 脱酸 10 sec 後の試料につき EPMA による定性分析を行なつた 結果を Photo. 3 に示した. ここで同定された介在物組 成は $\mathrm{FeO}$ を含む $\mathrm{CaO}$ 系介在物であることを確認する ことができた. さらに $\mathrm{Ca}$ 脱酸後 $8 \mathrm{~min}$ までに観察され た介在物組成の定量を試灭, 経時变化による各介在物中

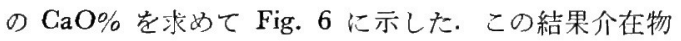
中の $\mathrm{CaO}$ 成分は $20 \sim 60 \%, \mathrm{FeO}$ 成分は $80 \sim 40 \%$ で あり， $\mathrm{CaO}$ 単体あるいは $\mathrm{CaO}$ に富えだ介在物は脱酸 初期においても認めることはできなかつた。

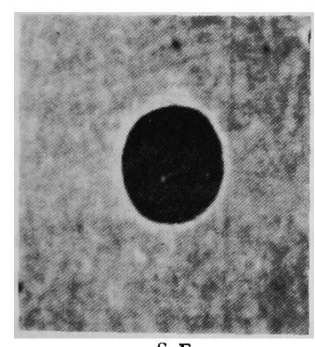

S.E.

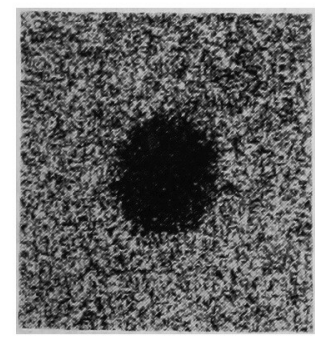

$\mathrm{Fe}$

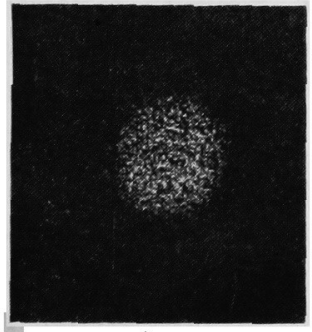

$\mathrm{Ca}$

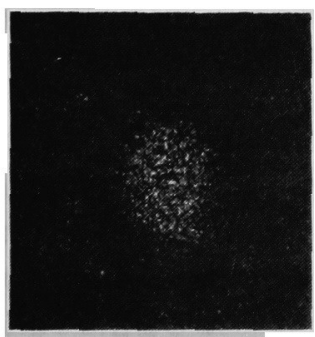

O
Photo. 3. Electron beam scanning images of oxide inclusions in pen sampling taken from liquid iron in a lime crucible $10 \mathrm{sec}$ after calcium addition.

$\times 1500$

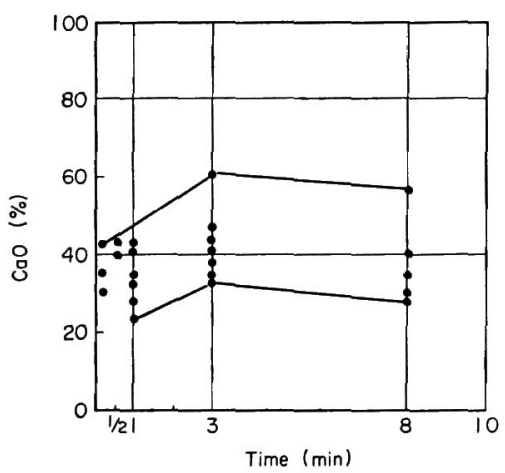

Fig. 6. $\mathrm{CaO}$ content of inclusions in pen samplings taken from liquid iron after adding $0.5 \%$ calcium.

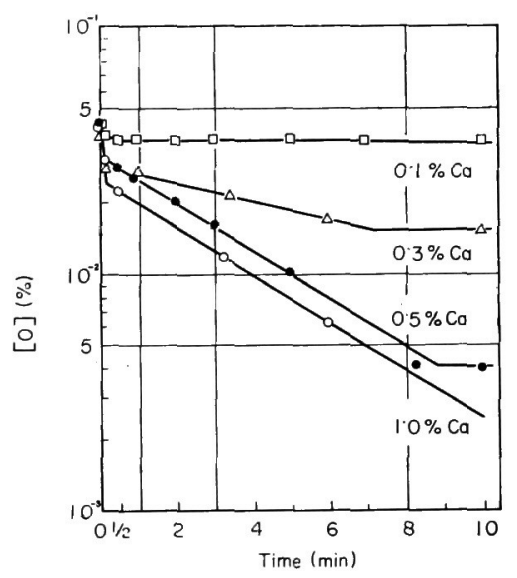

Fig. 7. Effect of the amount of calcium addition on the deoxidation of liquid iron.

\section{4 溶鉄の $\mathrm{Ca}$ 脱酸におよぼす $\mathrm{Ca}$ 添加量の影響}

Fig. 7 は Ca 添加量による経時变化と [O] との関 係を片対数で表示したもので西る. [O]は Ca の添加量 に応じて $10 \mathrm{sec}$ までの間に急激に減少し，その後はある 時間までほぼ直線的に低下した後一定となる傾向を示し ている. Ca 添加 $10 \mathrm{sec}$ 以後では時間 $t$ と全酸素量の対 数 $\ln [\mathrm{O}]$ の間には直線関倸が成立していることによ り，前述したごとき式(1)の関係が得られる。この場合 Ca 添加量ごとに脱酸の速度定数 $k$ を見積り Table 1 に 記載した。この過程での脱酸速度や脱酸継続時間は $\mathrm{Ca}$ 添加量によつて変化するが，Ca 0.5\% 以上の添加では 脱酸速度飞変化が認められない， Ca 添加直後にみられ る眖酸は，Ca を浴中に添加することによつて 惹起する 急激な反応によるものであり， $\mathrm{Ca}$ 気泡による溶鉄の㨨 乱作用によるものと考えられる. また図より溶鉄の $\mathrm{Ca}$ 
脱酸は，みかけ上 $\mathrm{Ca}$ 添加直後より $10 \mathrm{sec}$ までの Stage I, $10 \mathrm{sec}$ から酸素量の減少が終了するまでの Stage II, 定常状態にある Stage II の 3 段階に分けられることが 判明した。なおこれら各 Stageにおける脱酸挙動につい ては考察で述べる.

\section{$3.5 \mathrm{Ni}$ 系または $\mathrm{Cr}$ 系溶触鉄合金の Ca 脱酸}

$\mathrm{Ca}$ による溶鉄の脱酸過程をよく知るため, $\mathrm{Fe}-\mathrm{Ni}$ お よび Fe-Cr 合金を用いて脱酸実験を試みた：この場合 溶湯の被脱酸性は合金元素の種類や量によつて異なるゆ え， Ni または Cr 含有量を $30 \%$ まで変化した，HANSEN の状態図から Ca は $\mathrm{Ni}$ と相互に合金を作りうるし,

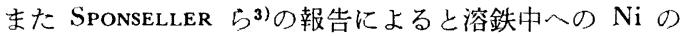
添加は Ca の活量を下げ溶解度の増加をもたらすことが 知られている. $\mathrm{Fe}-3 \% \mathrm{Ni},-10 \% \mathrm{Ni},-20 \% \mathrm{Ni}$, 打よび -30\% Ni をそれぞれ溶解して 0.5\% Ca の添加による 経時变化と $[\mathrm{O}]$ の関係を Fig. 8 に示した. $\mathrm{Fe}-3 \% \mathrm{Ni}$ の脱酸過程は溶鉄の場合に類似しみかけ上 3 段階に分け られるが，10\% Ni 以上の場合脱酸過程は 4 段階になつ ている. Ni 量の多いほどみかけ上初期の脱酸速度は遅 いが，脱酸限は $10 \mathrm{~min}$ 以降でもな抵下する傾向にあ る.このように Ni 量による脱酸過程の相違は $\mathrm{Ca} の$ 溶 解度, 脱酸生成物の組成やその浮上分朔性の差に基因す るものではないかと推察される. 他方 $\mathrm{Cr}$ を含む溶鉄に おける Ca の活量や溶解度におよぼす影響についての報 告はみあたらないが， Cr が酸素と結びつきやすく被脱 酸性を低下させる元素であることなどから，CrはCaの 溶解度を低下させるであるうと推定される. $\mathrm{Fe}-10 \% \mathrm{Cr}$ ， $-20 \% \mathrm{Cr}$ および $-30 \% \mathrm{Cr}$ 溶融鉄合金の脱酸挙動を Fig. 9 に示した. 図から明らかなとおり，溶鉄または $\mathrm{Ni}$ を含有した場合と異なつた脱酸挙動がみとめられる. すなわち Ca の沸騰効果による Stage I と比較的短時

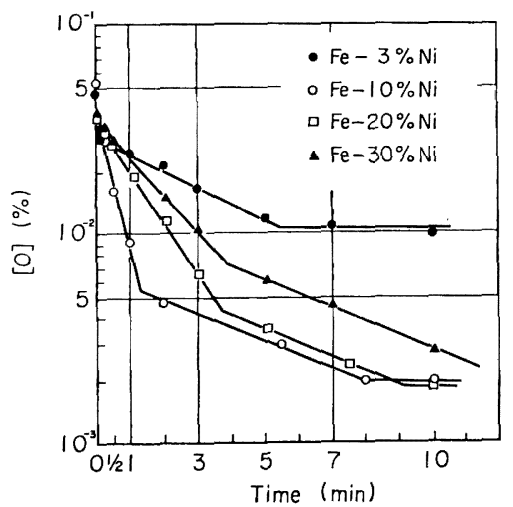

Fig. 8. Change in oxygen content of liquid ironnickel alloys after adding $0.5 \%$ calcium.

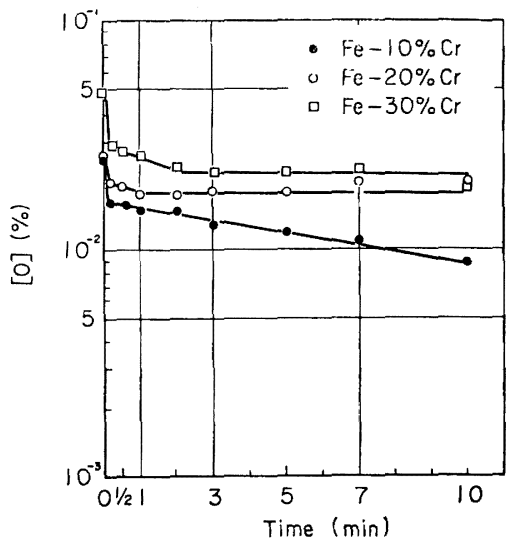

Fig. 9. Change in oxygen content of liquid ironchromium alloys after adding $0.5 \%$ calcium.

間の Stage II との過程で脱酸が終了し, Stage II の定常 状態へ移行している． Fe- Cr 合金では後述のごとく $\mathrm{Ca}$ の溶解度が低いことと, 活量係数 $f_{0}^{(\mathrm{Cr})}$ の值が小さいた め到達酸素量はかなり高く, $\mathrm{Ca}$ 単独添加では溶鉄また は $\mathrm{Fe}-\mathrm{Ni}$ 合金で確認されたような十分な脱酸は期待で きない.しかしながら介在物の顕微鏡観察の結果, $\mathrm{Ca}$ 添加以前に存在したスピネル型の $\mathrm{Cr}$ 酸化物は, $\mathrm{Ca}$ の添 加後は球状介在物に変化し, 介在物の形態と組成を変化 するという点で Ca の効果が期待される.

\section{6 溶鉄中 $\mathrm{Ca} の$ 溶解度について}

$\mathrm{CaO}$ 坩堝を使用し電解鉄を真空溶解した後, Ar 1 気 圧下であらかじめ Ca を 1.0\% 添加して $10 \mathrm{~min}$ 間保 持した。 この場合 $[\mathrm{O}]=50 \mathrm{ppm}$ まで低下した $[\mathrm{Ca}]=$ $9 \mathrm{ppm}$ の溶鉄に対し，再び Caを 0.5\%添加して直ちに 試料の吸引採取を行なつた，その経時変化による [Ca] と[O] について示したのが Fig. 10 である. Caを再 添加した $10 \mathrm{sec}$ 後には，鉄被覆 $\mathrm{Ca}$ クラッド材中の酸 尛が混入したためか溶鉄中の [O] は一時増加するが, 与ぐに低下した。ここでは溶鉄中における Ca の最大値 を次のようにして求めた。

$$
\underline{\mathrm{Ca}}=[\mathrm{Ca}]_{\text {total }}-(\mathrm{Ca})_{\mathrm{comp}}
$$

$(\mathrm{Ca})_{\operatorname{comp}}$ は $\mathrm{Ca}$ 化合物中の $\mathrm{Ca}$ 量のことで，実際に考 えられる化合物は $\mathrm{CaO}, \mathrm{CaS}, \mathrm{CaC}_{2}$ などである。これ

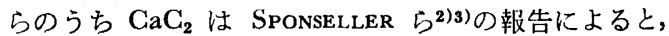
$\mathrm{C}<0 \cdot 87 \%$ の場合はほとんど生成し得ないことにより， 本実験においても $\mathrm{C}<0.01 \%$ の溶鉄を使用したためこ の化合物の生成を考慮しないことにする.したがつて，

$$
\mathrm{Ca}=[\mathrm{Ca}]_{\text {total }}-(\mathrm{Ca})_{\mathrm{CaO}}-(\mathrm{Ca})_{\mathrm{CaS}}
$$

として計算することができる． $0.5 \% \mathrm{Ca}$ の再湑加 $1 \mathrm{~min}$ 


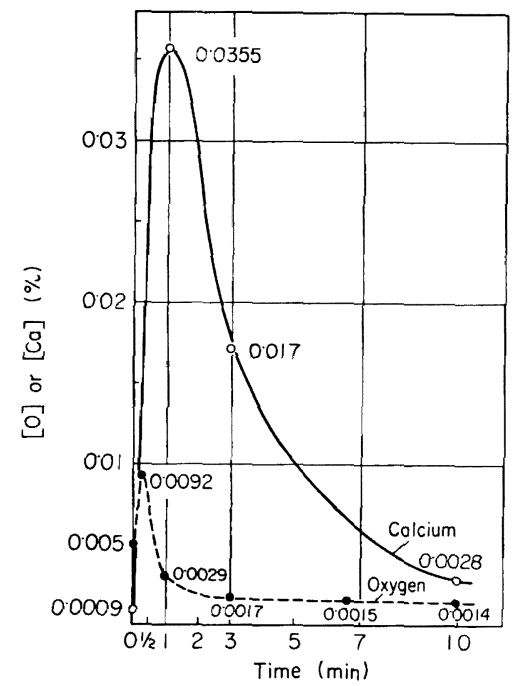

Fig. 10. Change in oxygen and calcium contents of liquid iron treated with (preliminary $1 \cdot 0 \%+0 \cdot 5 \%$ ) calcium with holding time.

後においては $[\mathrm{O}]=0.0029 \% ，[\mathrm{~S}]=0.003 \%$ なるゆ え，かりに溶鉄中の酸素および硫黄がすべて $\mathrm{CaO}, \mathrm{CaS}$ として存在していたとすると， $(\mathrm{Ca})_{\mathrm{CaO}}=0.0073 \%$, (Ca) $\mathrm{Cas}=0.0038 \%$ となり, また最大值を示した $[\mathrm{Ca}]$ total は 0.0355\% であるから式 (6) より Ca は 0.024 \%溶解していたことが計算される．この值は宮下引2)の $\underline{\mathrm{Ca}}=0.0103 \%$, 草川 ${ }^{4)}$ の $\mathrm{Ca}<0.018 \%$ よりは高いが, SPONSELler らの $\mathrm{Ca}=0.032 \%$ よりは低い.

\section{$3.7 \mathrm{Ca}$ の脱酸力について}

溶鉄中に Ca を添加した場合，Fig. 4 に示したよう に $0.5 \%$ 添加で $[\mathrm{O}]=39 \mathrm{ppm}$ ，またFig. 10 に打ける $\mathrm{Ca}$ 過剩添加の実験では $[\mathrm{O}]=14 \mathrm{ppm}$ まで低下した。 これは溶鉄中で $\left[\mathrm{Ca}_{(v)}\right.$ または $\left.\underline{\mathrm{Ca}}\right]+\mathrm{O} \rightarrow(\mathrm{CaO})$ の反 忍で主として $\mathrm{CaO}-\mathrm{FeO}$ 介在物として系外八分䜅したこ とが推定される.ここで Caの脱酸力を求めるため真空 加圧溶解炉を用い，Ar 8 気压の加圧雾国気下で溶鉄500 $\mathrm{g}$ に対して粒状金属 $\mathrm{Ca}$ を $50 \mathrm{~g}$ 表面添加し, $1600^{\circ} \mathrm{C}$ で液相Ca-溶鉄が十分保たれるようにして $5 \mathrm{~min}$ 間保持 した. その後約 $3 \mathrm{~min}$ 間で脱ガスし，Ar 1 気圧下にお いて不透明石英管で溶鉄を所定時間ごとに吸引採取し, 経時変化による $[\mathrm{O}]$ 上 $[\mathrm{Ca}]$ との関係を求めたのが Fig. 11 である. $5 \mathrm{~min}$ 間の加圧と $3 \mathrm{~min}$ 間の脱ガス後にお いても $0.02 \%$ 程度の酸素が残留していたのは，加圧下 で $\mathrm{Ca}$ が多量に添加されたため， $\mathrm{CaO}$ 成分の多い介在 物が㠜集浮上しにくいように微細に分散したことに起因

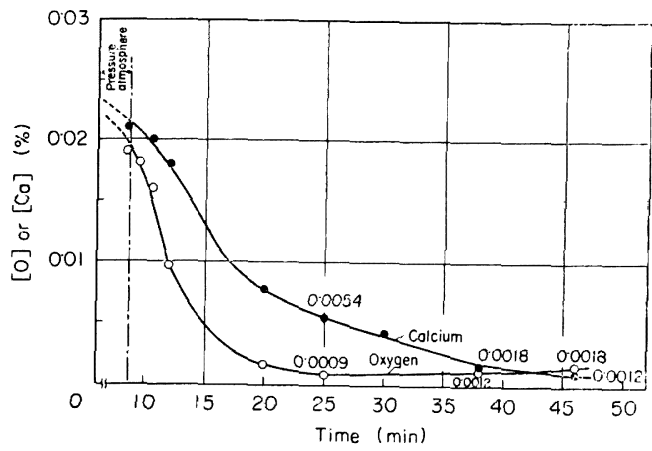

Fig. 11. Change in oxygen and calcium contents of liquid iron at argon $1 \mathrm{~atm}, 1600^{\circ} \mathrm{C}$. The melt was previously treated with $10 \%$ granular calcium at argon $8 \mathrm{~atm}$.

寸るのではないかと考えられる. 25 min後には最低酸素 值として $9 \mathrm{ppm}$ が水められ，その後若干增加の傾向が みよめられた. $25 \mathrm{~min}$ 以後の各時点に存在した酸素はす ベてOであると推定されるが，同じ時点での[Ca]を用 いてみかけ上の $K^{\prime}{ }_{\mathrm{Ca}}=[\mathrm{Ca} \%] \cdot\left[\mathrm{O}^{\circ}\right.$ o] を求めてみたと ころ, $25 \mathrm{~min}$ 後には $K^{\prime}{ }_{\mathrm{Ca}}=4 \cdot 86 \times 10^{-6}$, また $38 \mathrm{~min}$ 後, 46 min後ではそれたれ $K^{\prime}{ }_{\mathrm{Ca}}=2 \cdot 16 \times 10^{-6}$ と見栍ら れた。

\section{8 溶鉄の脱硫について}

$\mathrm{CaO}$ 坩堝を用いた溶鉄の脱硫は，式（）のごとく示 された溶銑または高炭素溶鉄に関与る研究5)6) が主であ り，011\%C 以下の浴鉄に関立る脱琉実駗はほとんど見 うけられない.

$$
(\mathrm{CaO})+\underline{\mathrm{S}}+\underline{\mathrm{C}} \rightarrow(\mathrm{CaS})+\{\mathrm{CO}\}
$$

ここでは $\mathrm{CaO}$ 坩堝中で溶解した $\mathrm{C}=50 \mathrm{ppm}, \mathrm{S}=80$ $\mathrm{ppm}, \mathrm{O}=500 \mathrm{ppm}$ 程度苔公む電解鉄溶湯に Si $0.2 \%$, $\mathrm{Al} 0.2 \%$, Ce $0.2 \%$, Ca 0.5\%ををれぞれ Ar 1 気圧 下で単独に添加し，各溶晹の経時变化に対する[S]を調 ベ Fig. 12 に示した. Si 添加による脱硫は， $\mathrm{CaO}$ およ び $\mathrm{CaF}_{2}$ よりなる塩基性唗埫またはとれらを溶鎆涪とし て使用した炭素鋼溶湯において進行与ることが認められ ているが6)7)，本实䮖条件のごとき比較的初期酸素の高 い電解鉄溶湯に対して脱硫は弪められなかつた。 Ce や $\mathrm{Ca}$ は S と親和力の強い元素であり, 本実験の場合初 期 [O] の高いこと, 初期 [S] の低いことでいずれも 脱硫はごく初期に認められたにすぎない.これらの添加 元素は次式に示すごとき $\mathrm{S} と の$ 親和力にもとずく直接脱 硫反応であり， $\mathrm{MgO}$ または $\mathrm{Al}_{2} \mathrm{O}_{3}$ 圤㶡でも起こり得る 区応と考觉らる.

$$
2 \underline{\mathrm{Ce}}+3 \underline{\mathrm{S}} \rightarrow\left(\mathrm{Ce}_{2} \mathrm{~S}_{3}\right)
$$




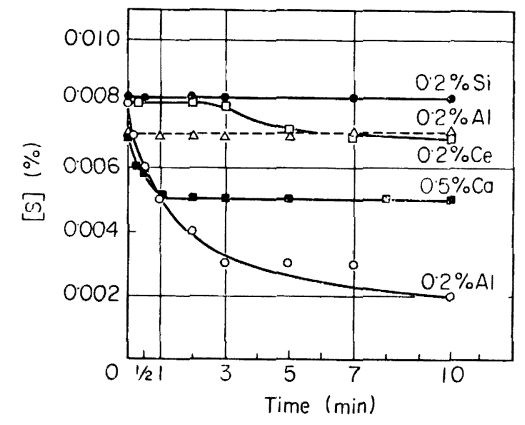

Fig. 12. Change in sulphur content of liquid iron in lime crucible after addition of various deoxidizers. A dotted line shows the effect of aluminium addition in an alumina crucible.

$$
\mathrm{Ca}_{(v)} \text { または } \underline{\mathrm{Ca}}+\underline{\mathrm{S}} \rightarrow(\mathrm{CaS})
$$

これらに対しAIを添加したところ顕著な脱硫作用が認 められた，一般に低炭素溶鉄に対し Al 単独添加の脱硫 作用に関する研究はみあたらないが，Al を使用した場 合， $\mathrm{Al}_{2} \mathrm{~S}_{3}$ として脱硫作用を果たすという郝告8)があり， また著者らは前報で $\mathrm{CaO}+\mathrm{CaF}_{2}$ 溶滓下で $\mathrm{SiMn}$ 脱酸 後 $\mathrm{Al}$ を添加することで脱硫の起こることを示しだ). 本 実験の溶解過程で吸引採取した試料中の介在物組成を EPMA で調べた結果， $\mathrm{Al}_{2} \mathrm{~S}_{3}$ または硫化物系介在物を検 出することはできなかつた。 また $\mathrm{Al}_{2} \mathrm{O}_{3}$ 坩堝を使用して $0 \cdot 2 \% \mathrm{Al}$ を添加した結果をも Fig. 12 に示したが，この 場合には脱硫は全く認められなかつた。

以上のごとき $\mathrm{CaO}$ 㘿佩を使用して $\mathrm{Al}$ 添加による脱 硫作用を詳しく知るため，溶鉄の初期 [O]。がほぼ 500 ppm で初期 $[S]_{0}$ を 0.014\%，0.023\%，0.14\%に変化 した 3 チャージにつき，それぞれ Ar 1 気王下で $0.2 \%$ $\mathrm{Al}$ を添加した場合の脱酸と脱硫作用を淍べた。との結 果いずれも同時に脱酸と脱硫の起こる傾向が認められ， $10 \mathrm{~min}$ 後に [O] はそれぞれ 18，5，7ppm に[S]は それぞれ 30，20，50pom まで減少し，脱硫珤は79\%， 91\%，96\% を示しいずれも顕著であつた. Fig. 13 は実 験結果の一例である.この場合 $[\mathrm{O}]_{0}=0.042 \%,[S]_{0}=$ $0.023 \%$ の溶鉄であるが， $\mathrm{Al}$ 添加直後より同㭙に脱酸 脱硫の傾向が涊められ，10 min 後には [O] $=5 \mathrm{ppm}$, $[\mathrm{S}]=20 \mathrm{ppm}$ まで著しい低減を示した．なお $60 \mathrm{~min}$ 経過しても復硫，復酸はほとんどみられない.

このような $\mathrm{CaO}$ 坩堝または $\mathrm{Al}_{2} \mathrm{O}_{3}$ 坩堝を使用して $\mathrm{Al}$ 添加を行なつた場合, 経時変化による残留 [Al] を 調べたのが Fig. 14 である、いずれの場合も溶鉄中にお ける不純物としての $\mathrm{Al}$ 望は 20ppm 以下であつたが，

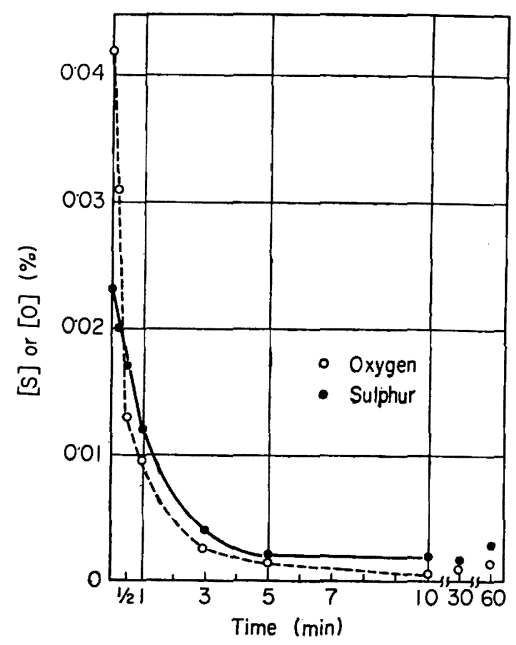

Fig. 13. Change in oxygen and sulphur contents of liquid iron in lime crucible after adding $0.2 \%$ aluminium.

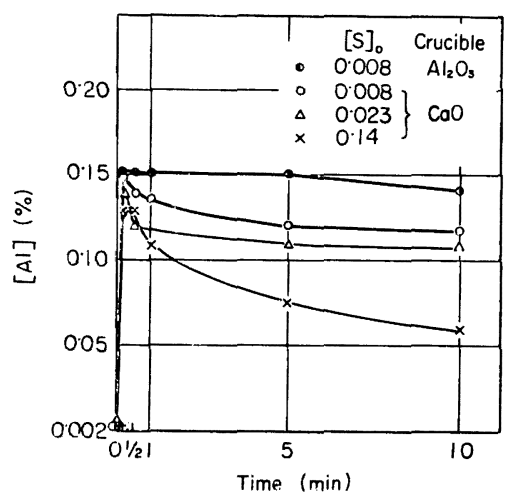

Fig. 14. Change in total aluminium in liquid iron containing various initial sulphur content after adding $0 \cdot 2 \%$ aluminium.

$0.2 \% \mathrm{Al}$ 添加直後の [Al] はほぼ $0.015 \%$ 前後となり 初期酸素量に見合つた $\mathrm{Al}$ 量の $0.05 \%$ が脱酸に消耗さ

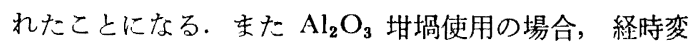
化による [Al] の変化はほとんど認められなかつたのに 反し, $\mathrm{CaO}$ 坩佩の場合, 初期 $[\mathrm{S}]_{0}$ の高い溶湯ほど $\mathrm{Al}$ 添加直後の経時変化において $[\mathrm{Al}]$ の減少が顕著であつ た。をた経時変化による残留 [Ca] を調べたが，いずれ の場合も検出されないか，10ppm 以下で $\mathrm{CaO}$ 坩堝か らの混入を認めることはできなかつた. 次に初期 $[\mathrm{S}]$ 。 $=0.14 \%$ を含む溶鉄の $\mathrm{Al}$ による脱硫実験に使用した $\mathrm{CaO}$ 坩堝壁より溶鉄と接触した表面部分の耐火物を採 収し，粉末X線回折を試みたがその解析結果をPhoto. 4 に示した. Photo. 4(a) は未使用の $\mathrm{CaO}$ 坩堝壁より 
(a)

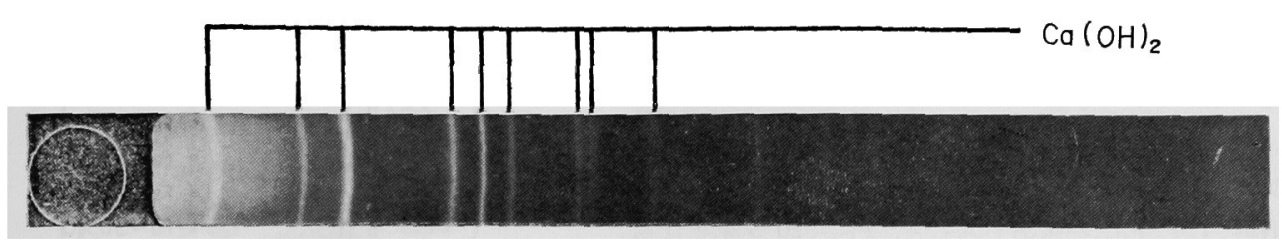

(b)

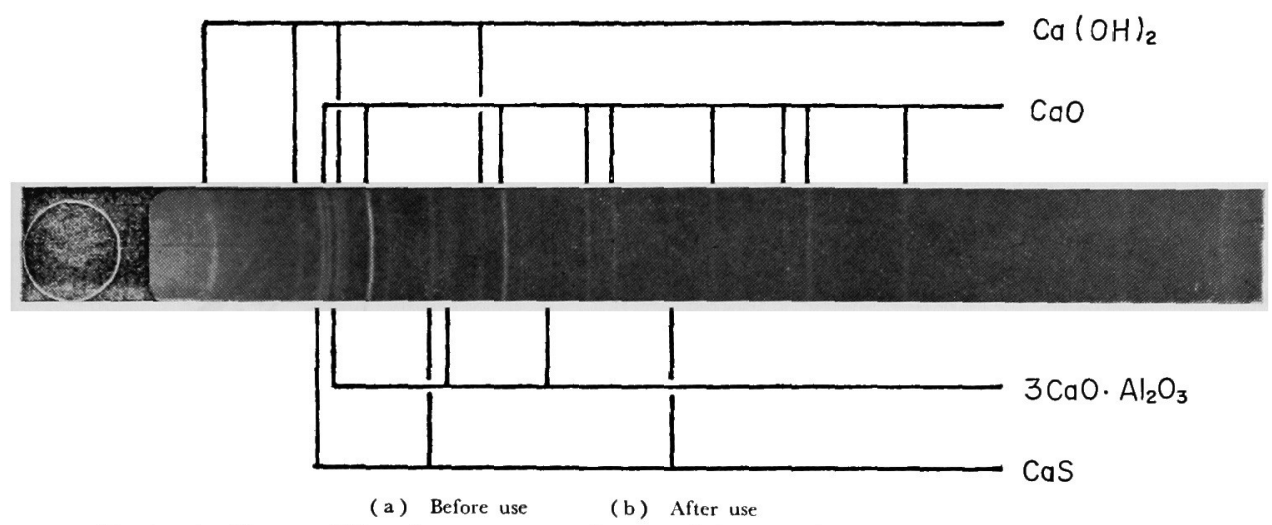

Photo. 4. X-ray diffraction patterns of reacted layers of the lime crucible.

の場合で, $\mathrm{Ca}(\mathrm{OH})_{2}$ のみ検出された。本来は $\mathrm{CaO}$ の みであるべきところ試料の調整中 $\mathrm{CaO}$ 粉末が大気中の 水分を吸収したためと考えられる。 これに反し，Photo. 4 (b)から明らかなように使用後の坩佩壁には $\mathrm{Ca}(\mathrm{OH})_{2}$ 以外に $\mathrm{CaO}, 3 \mathrm{CaO} \cdot \mathrm{Al}_{2} \mathrm{O}_{3}$ ‡た $\mathrm{CaS}$ の存在が確認さ れるに至つた。また坩堝壁表面部分における $\mathrm{Al}$ や $\mathrm{S}$ 成 分の化学分析結果でも未使用の場合, $\mathrm{Al}=0.005 \%, \mathrm{~S}=$ $0.017 \%$ であつたが，使用後の坩堝壁下部および晹境部 分の炉壁で $\mathrm{Al}=2 \cdot 6 \sim 2.8 \%, \mathrm{~S}=1 \cdot 5 \sim 1 \cdot 9 \%$ にそれぞ れ富化していることが判明した. これらの事䒠より $\mathrm{Al}$ 添加による著しい脱硫作用は， $\mathrm{CaO}$ 坩佩壁表面の関与 していることが汴明らかとなつた。

\section{4. 考察}

\subsection{Ca の有効作用効率}

ここでは Ca を添加したとき実際に使用された Caの 量完見積り，その值を $\mathrm{Ca}$ の有効作用効率 $F_{\mathrm{C}_{a}}$ として 次のように定義する。

$$
F_{\mathrm{Ca}}=\left([\mathrm{Ca}]_{W} /[\mathrm{Ca}\rfloor_{a}\right) \times 100
$$

$[\mathrm{Ca}]_{a}$ : 溶鉄に対する Ca 添加量 $(\mathrm{wt} \%)$

$[\mathrm{Ca}]_{W}$ : 溶湯中に拈いて何らかの形で作用した Ca の 溶鉄に対する割合 $(w t \%)$

式(10)で $[\mathrm{Ca}]_{W}$ を見積らなければならないが，Ca の 脱酸過程より次式のごとく仮定する.
Table 2. Contents of oxygen and calcium in molten iron after the addition of $0.5 \%$ calcium.

\begin{tabular}{|c|c|c|c|c|c|c|}
\hline \multirow{2}{*}{ Element } & \multirow{2}{*}{ Initial } & \multicolumn{5}{|c|}{ Time after the $\mathrm{Ca}$ addition } \\
\hline & & $10 \mathrm{sec}$ & $1 \mathrm{~min}$ & $3 \mathrm{~min}$ & $5 \mathrm{~min}$ & $10 \mathrm{~min}$ \\
\hline $\begin{array}{l}{[\mathrm{O}]} \\
{[\mathrm{Ca}]}\end{array}$ & $\begin{array}{c}0.045 \\
-\end{array}$ & $\begin{array}{l}0.030 \\
0.015\end{array}$ & $\begin{array}{l}0.025 \\
0.014\end{array}$ & $\left|\begin{array}{l}0.016 \\
0.009\end{array}\right|$ & $\mid \begin{array}{l}0.010 \\
0.005\end{array}$ & $\begin{array}{l}0.0039 \\
<0.001\end{array}$ \\
\hline
\end{tabular}

$$
[\mathrm{Ca}]_{W}=[\mathrm{Ca}]_{W(\mathrm{i})}+[\mathrm{Ca}]_{W(\mathrm{ij})}
$$

$[\mathrm{Ca}]_{W(\mathrm{i})}: \mathrm{Ca}$ 添加初期の沸騰効别による脱酸上 $1 \mathrm{~min}$ までの脱酸は，みかけ上溶鉄中の $\mathrm{Ca}$ 量の減少がみら

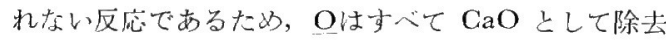
されたものとみなして央められる值である。

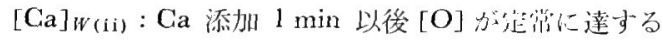
までの脱酸は， $\mathrm{CaO}-\mathrm{FeO}$ 介在物として系外への分離 過程であると考えられるので，またこの過程での $\mathrm{Ca}$

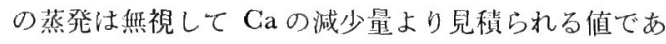
る.

以上のように定莪した $F_{\mathrm{Ca}}$ 在 $0.5 \% \mathrm{Ca}$ 添加した溶 鉄の場合について求めてみる.この埸合, 経時变化によ る [O]と [Ca] の变化は Table 2 に示したとおりて ある. 式(11)占り

$[\mathrm{Ca}]_{W(\mathrm{i})}=($ 初期酸素量 $-\mathrm{Ca}$ 添加 $1 \mathrm{~min}$ 後の酸素量 $)$ $\times 40 / 16$ 


$$
=(0.045-0.025) \times 40 / 16=16=0.05
$$

$[\mathrm{Ca}]_{W(\mathrm{ii})}=0 \cdot 014-0 \cdot 001=0 \cdot 013$

$[\mathrm{Ca}]_{W}=0 \cdot 063(\%)$

したがつて式(10)より， $F_{\mathrm{Ca}}=(0 \cdot 063 / 0 \cdot 5) \times 100=12 \cdot 6$ $(\%)$ 上見積られる. $0.2 \% \mathrm{Ca}$ を添加した溶鉄の場合, 同㥞にして $F_{\mathrm{C}_{3}}$ を求めてみると， $F_{\mathrm{Ca}}=20 \cdot 3 \%$ 上なる. 与な⿰ち $\mathrm{Ca}$ 添加量の少ない方が効辦がよい。ここで $0.5 \% \mathrm{Ca}$ 脱陵の場合, $\mathrm{Ca}$ 添加 $1 \mathrm{~min}$ 以後より $10 \mathrm{~min}$ までの [Ca] の減少と [O] の減少より采外へ分離し た介在物の平均組成を推定してみた，減少した酸素量が すべて $\mathrm{CaO}$ として除去されたと仮定すると，(0.025$0 \cdot 0039) \times 40 / 16=0 \cdot 0525(\%) の \mathrm{Ca}$ の減少がみられなけ ればならないしかるに実際は，0.014-0.001=0.013 $(\%) の \mathrm{Ca}$ の減少なので酸素量の減少のうち $\mathrm{CaO}$ とし ての減少は $(0 \cdot 013 / 0 \cdot 0525) \times 100=24 \cdot 8(\%)$ 程度にすぎ ないと考えられる。このことは系外へ分離した脱酸生成 物の組成は，平均して $25 \% \mathrm{CaO}-75 \% \mathrm{FeO}$ 程度のもの であつたと推定される.この值は 3.3 で述べた EPMA による介在物組成の分析結果とほぼ近似している.

\section{$4.2 \mathrm{Ca}$ による溶鉄の脱酸過程}

溶鉄， $\mathrm{Ni}$ 系および $\mathrm{Cr}$ 系溶融鉄合金などの Ca によ る脱酸実験については，Fig. 7，8，9に示したようにい ずれも同一脱酸条件下にもかかわらず溶湯の種類によつ てみかけ上著しい差が認められた。そこでまず Ca の添 加量を変化した溶鉄における経時变化と残留 [Ca] の閂 係について示したのが Fig. 15 である. [Ca] の変化よ りわかることは, $\mathrm{Ca}$ 添加直後の沸騰猊乱効果による $\mathrm{Ca}_{(v) \rightarrow \mathrm{Ca}}$ の反応は, $\mathrm{Ca}$ の添加量や添加方法のいかん によらず約 $10 \mathrm{sec}$ までに完了していると考えられるにも かかわら-゙, 残留 [Ca] は $1 \mathrm{~min}$ 程度までほとんど減

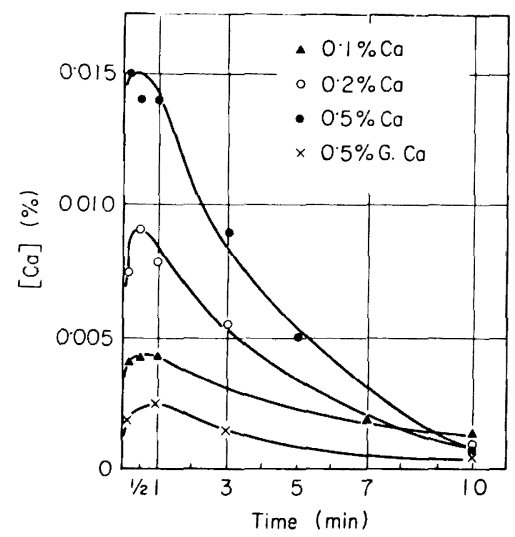

Fig. 15. Change in calcium content of liquid iron after adding various amounts of calcium. G.Ca : Granular calcium

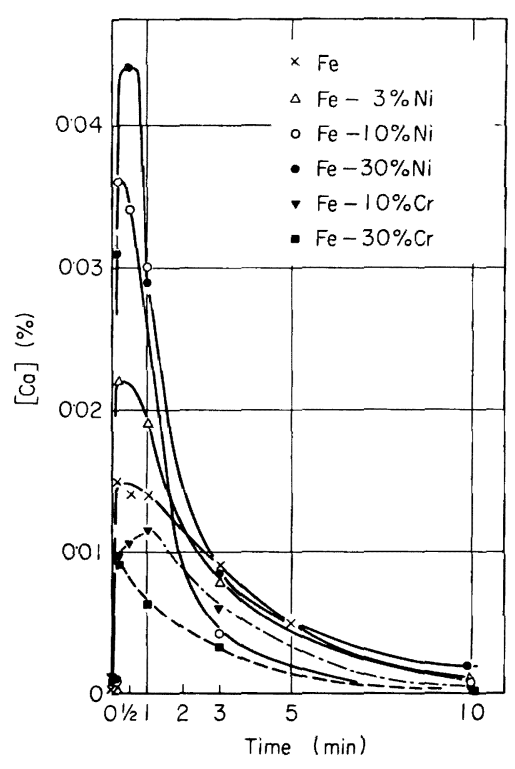

Fig. 16. Change in calcium content of liquid iron and liquidiron alloys after adding $0.5 \%$ calcium.

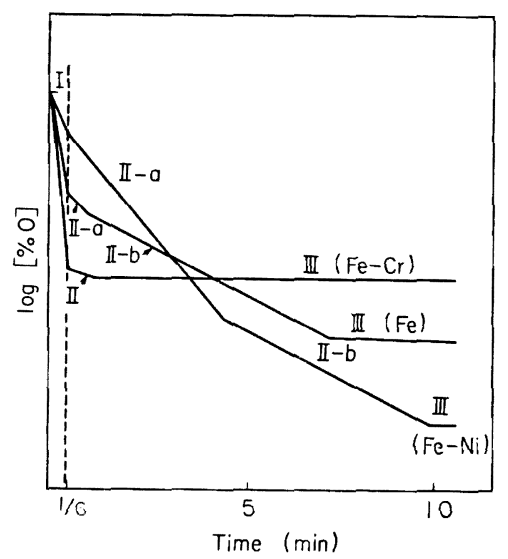

Fig. 17. Schematic representation of the calcium deoxidation process of liquid iron and liquid iron alloys.

少がみられない。また同様な傾向は Fig. 16 に示した $\mathrm{Ni}$ 系, Cr 系鉄溶湯の場合にも認められ，Ca 添加後約 $1 \mathrm{~min}$ 以内に [Ca] の最大值が得られ, $10 \mathrm{~min}$ 後には 溶鉄の場合と同様いずれも $20 \mathrm{ppm}$ 程度に低下している. 溶鉄の場合に比較して $\mathrm{Ni}$ が含まれるとその含有量に応 じて $[\mathrm{Ca}]$ の最大残留量は增加するようになり，他方 $\mathrm{Cr}$ を含むようになると逆に低下する傾向が認められ, Ni たは Cr を含有することによる Ca の溶解度の相違が明 らかである。これらの事实より， Ca の溶鉄への溶解過 


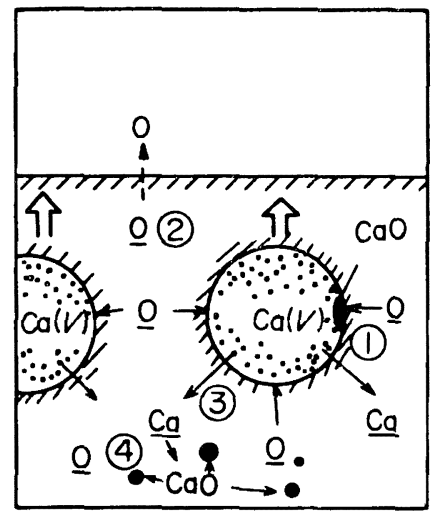

Stage I

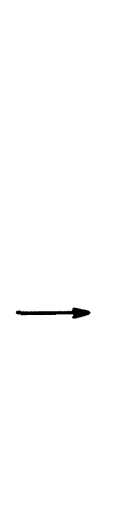

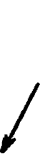

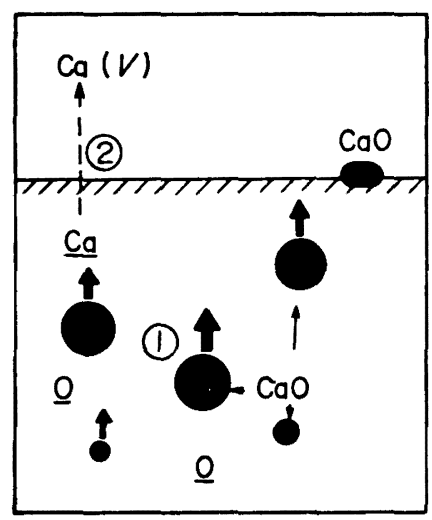

Stage $\mathbb{I}-b$

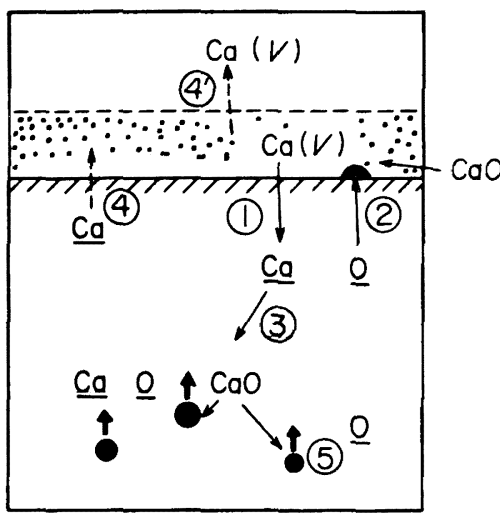

Stage II-a
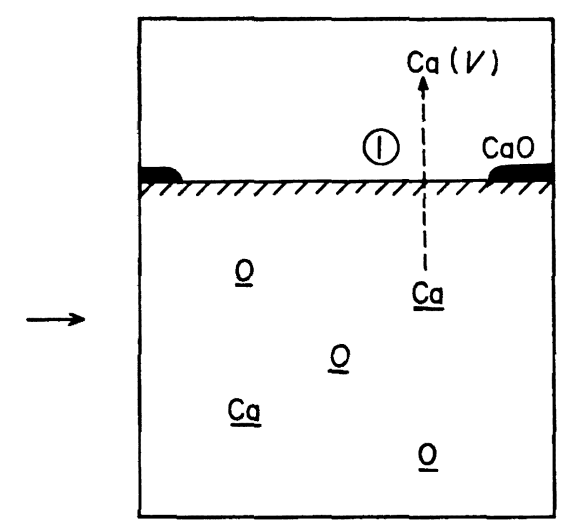

Stage III

Fig. 18. Schematic illustration of the calcium deoxidation process corresponding to Fig. 17.

程は $\mathrm{Ca}$ 添加直後の 沸騰段階でのみ完了するのではな く, 溶解度の関係で $1 \mathrm{~min}$ 間程度は他のなえらかの過程 によつても継続していると考えられる。

一方, 攬拌溶湯に打ける脱酸速度の变化は, みかけ上 溶鉄では 3 段階， $\mathrm{Ni}$ 系では 4 段階， $\mathrm{Cr}$ 系では 2 段階に 分類されることは前述したとおりであるが，これらを Fig. 17，Fig. 18 に略図化し各段階について検討した.

Stage I：この段階は Ca 添加後 $10 \mathrm{sec}$ までの脱酸過 程であり, $\mathrm{Ca}$ 気泡の沸騰貿乱奻果による脱酸である. $\mathrm{Ca}$ を溶鉄中に添加すると浴温度が $\mathrm{Ca}$ の沸点より高いた
めに $\mathrm{Ca}$ は急澈に気化し $\mathrm{Ca}$ 父泡となつて溶湯中を上昇 する.この過程で考えられる反応は次のとおりである.

(1) $\mathrm{Ca}_{(v)}+\mathrm{O} \rightarrow \mathrm{CaO}$ この反応は父泡界面で起こり, 脱酸生成物は気泡に付着して系外一除去される.

(2) $\mathrm{Ca}$ 気泡の溶湯掜乱にともなら脱ガス作用

(3) $\mathrm{Ca}_{(v)} \rightarrow \underline{\mathrm{Ca}}$ (4) $\mathrm{Ca}+\underline{\mathrm{O}} \rightarrow \mathrm{CaO}$

(3) $\mathrm{Ca}$ 蒸気の溶鉄中への溶解であり, (4)は溶解した $\mathrm{Ca}$ の脱酸反応であるが，この段階では脱酸生成物の系外 の分剀はきわめて少ないと考光られる.これらのうち(1) (2) は直接的な脱酸であつて $\mathrm{Ca}$ の溶解度と密接な関係が 


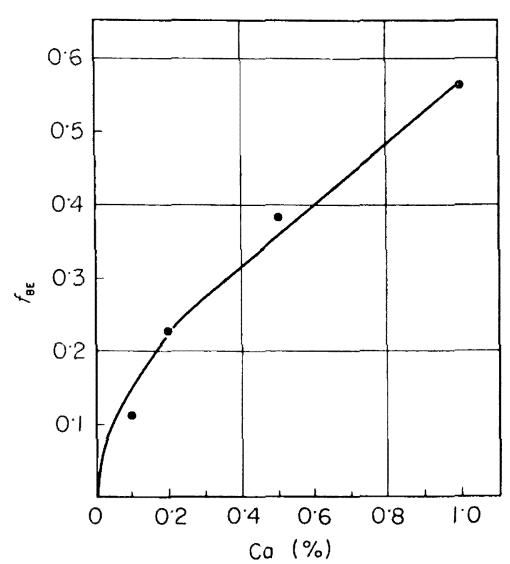

Fig. 19. Deoxidation degree expressed by boiling effect $\left(f_{\mathrm{BE}}\right)$ for initial 10 seconds after adding various amounts of calcium. $f_{\mathrm{BE}}$ $=\left([\mathrm{O}]_{0}-[\mathrm{O}]_{10^{\prime \prime}} /[\mathrm{O}]_{0}\right)$.

存在し, (3)の溶解速度によつて著しく左右されるであろ うし，(1)や(3)の進行にともなつて気泡は減少し，その反 応界面積や掜乱作用は低下する。 またこの段階で沸騰效 果に相当する脱酸度 $f_{\mathrm{B} \cdot \mathrm{E}}$ (B.E : Boiling Effect) を式 (12)のごとく表わし,

$$
f_{\mathrm{B} \cdot \mathrm{E}}=\left([\mathrm{O}]_{0}-[\mathrm{O}]_{10^{\prime \prime}}\right) /[\mathrm{O}]_{0} \cdots
$$

$[\mathrm{O}]_{0}$ : 初期酸素量 $(w t \%) \quad[\mathrm{O}]_{10^{\prime \prime}}$ : Ca 添加 $10 \mathrm{sec}$ 後の酸素量 $(\mathrm{wt} \%)$

溶鉄における Ca 添加量との関係を求めたところ, Fig. 19に示したような相関関係の存在することがわかつた。 また同栐に Fig. 20 には $\mathrm{Ni}$ や Cr を含む溶鉄について $0.5 \% \mathrm{Ca}$ 添加による [Ca] の最大残留量と $f_{\mathrm{B} \cdot \mathrm{E}}$ との 関係示した．以上から溶鉄に対しては Ca 添加量の多 いほど，をた Ca の溶解度の小さい Fe-Cr 溶湯などが 沸滕効里に上る脱酸度 $f_{\mathrm{B} \cdot \mathrm{E}}$ は大きいことが判明した。 Cr 系の脱酸度は注ぼこの Stage I の過程に依存するが， $\mathrm{Ni}$ 系の場合は主要な脱酸過程ではないことが Fig. 17 より明らかである。

Stage II-a：この段階は特に $\mathrm{Ni}$ 系溶晹に相当するが， $\mathrm{Ca}$ の溶解と脱酸生成物の系外八の分䠰が其存して起こ る過程と考える.

(1) $\mathrm{Ca}_{(v) \rightarrow} \rightarrow \mathrm{Ca}$ 溶沙中の Caは過饱和に達していない ゆえ，浴表面に存在が仮想される $\mathrm{Ca}$ 䔩父層から溶鉄表 面を通じての溶解

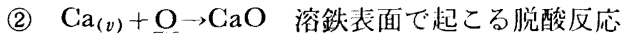

(3) $\mathrm{Ca}+\mathrm{O}^{-}, \mathrm{CaO}$ 溶解 $\mathrm{Ca}$ の脱酸反応

(4) $\mathrm{Ca}-, \mathrm{Ca}_{(v)}$ 溶解 $\mathrm{Ca}$ の蒸発

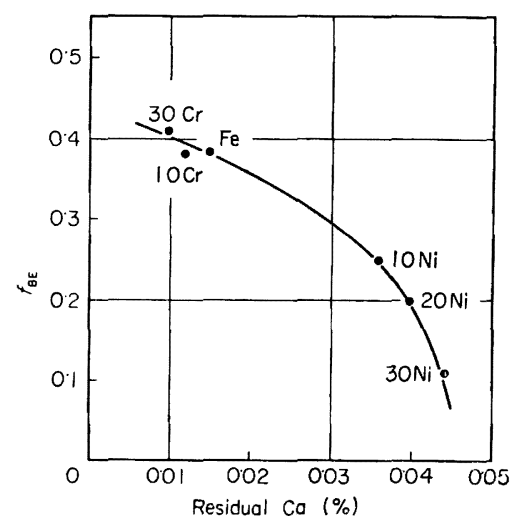

Fig. 20. Relation between the boiling effect $\left(f_{\mathrm{BE}}\right)$ and the maximum residual calcium content of liquid iron and liquid iron alloys.

(5) 脱酸生成物の系外への分離などが考えられる.

Stage II -b : この段階は一次脱酸生成物である $\mathrm{CaO}$ 系 介在物の系外人の分嚄過程である.

(1) Stage I の (4), Stage II-a の(3)で生成された $\mathrm{CaO}$ 系介在物の分離

(2) 溶解 $\mathrm{Ca}$ の蒸発

Stage III：この段階では脱酸が終了し，残存する Ca が 時間とともにしだいに蒸発してゆく過程である.この段 階に到達するまでの時間は以上述べた Stage I〜II まで の過程に依存するが，実駼結果では Ca の溶解度の大き い $\mathrm{Fe}-\mathrm{Ni}$ 系では遅く, 溶解度が小さい $\mathrm{Fe}-\mathrm{Cr}$ 系では速 い上うである。したがつて実用的には $\mathrm{Ni}$ 系溶湯に対す る Ca 脱酸の場合, 添加後の保持時間を長くすること， C r 系溶湯の場合は短くすることが脱酸矨果を十分にす る上で重要であると考える.

\section{$4.3 \mathrm{Ca}$ 脱酸の平衡定数について}

一般に金属 $\mathrm{Ca}$ を溶鉄類の脱酸剂に用いた場合， $\mathrm{Ca}$ の 蒸気压から明らかなごとく $\mathrm{Ca}$ の蒸発速度はきわめて大 きい。したがつて溶鉄中の $\mathrm{CaO}$ が完全に除去され，溶 解酸素量のみとみなされる時点では, 溶解 $\mathrm{Ca}$ はかなり 蒸発し減少していると考えられる. 現在のところ $\mathrm{Ca}$ と $\mathrm{O}$ との平鿉定数については $\mathrm{Ca} ， \mathrm{O}$ の正確な值を決定で きる方法がないため正確に求めることはできない，しか しながら本実験の場合の最低の酸素量は，Ca を添加す ることによつて得られたその時点での $\mathrm{Ca}$ と平衡してい るOの值であると考えてみることにする．成分分析は全 分析であるが，[Ca]，[O] は溶鉄中に溶解した形で存在 するとみなす．この状態の反応は式(13)が平衡状態に達

$$
[\mathrm{Ca}]+[\mathrm{O}]=(\mathrm{CaO})
$$


したことを意味する. 3.7 の Fig. 11 から 38 min 後に は $[\mathrm{O}]=0.0012 \%,[\mathrm{Ca}]=0.0018 \%$ であつた. 反応式 (13)の平衡常数 $K_{\mathrm{Ca}}$ を求めてみると,

$\log K_{\mathrm{Ca}}=\log [\% \mathrm{Ca}][\% \mathrm{O}]+\log f_{\mathrm{Ca}}+\log f_{\mathrm{O}} \tau$ 表わされる.

$$
\log f_{\mathrm{Ca}}=e_{\mathrm{Ca}}^{(\mathrm{O})}[\% \mathrm{O}]+e_{\mathrm{Ca}_{\mathrm{a}}}^{(\mathrm{Ca})}[\% \mathrm{Ca}]
$$

ここで $e_{\mathrm{Ca}}^{(\mathrm{Ca})}[\% \mathrm{Ca}]=0$ と仮定する，また

$$
\log f_{\mathrm{O}}=e_{\mathrm{O}}^{(0)}[\% \mathrm{O}]+e_{\mathrm{O}}^{(\mathrm{C}(\mathrm{n})}[\% \mathrm{Ca}]
$$

$f_{i}$ は成分 $i$ の活量係数, $e_{i}^{(j)}$ は成分 $i$ に対する成分 $j$ の 相互作用助係数である. 学振の推奖值 ${ }^{10)}$ により, $e_{0}^{(0)}=-$ 0.17 at $1600^{\circ} \mathrm{C}$, 小林氏ら ${ }^{1)}$ より $e_{\mathrm{O}}^{(\mathrm{Ca})}=-535, e_{\mathrm{Ca}}^{(0)}=-$ 1330, 式(13)，(14) および (15) に必要な数值を代入す れば,

$\log K_{\mathrm{Ca}}=\log a_{\mathrm{Ca}} \cdot a_{0}=-8 \cdot 23\left(1600^{\circ} \mathrm{C}\right), \quad K_{\mathrm{Ca}}=5 \cdot 9 \times$ $10^{-9}$ を得る。

\section{4 脱硫作用について}

本実験のごとく，Ar 1 気圧下で G をほとんど公まぬ 溶鉄に対して $\mathrm{Al}$ 添加による脱硫反応は次のように考元 られる. Fig. 14 から明らかなとおり $\mathrm{CaO}$ 坩堝を使用 した場合, 初期硫黄量 $[\mathrm{S}]$ 。の高い試料ほど経洔変化に よる残留 $[\mathrm{Al}]$ の低下減少が顕著であり，坩堝壁の $\mathrm{CaO}$ と添加した Al が何らかの形で脱硫反応に寄与したこと が推測される.この場合残留 [Ca] は全く検出されなか つたことから,減圧下の高温で起こるような $\mathrm{CaO} の \mathrm{Al}$ による熱還元反応，すなわち，

$6(\mathrm{CaO})+2 \underline{\mathrm{Al}} \rightarrow 3 \underline{\mathrm{Ca}}+\left(3 \mathrm{CaO} \cdot \mathrm{Al}_{2} \mathrm{O}_{3}\right)$

式(16)で溶出した $\mathrm{Ca}$ が脱硫作用を果たすとは考えにく い.一方化学分析から, 使用した坩堝壁表面に扮ける $\mathrm{Al}$ やSの富化，またX線回折の結果から $3 \mathrm{CaO} \cdot \mathrm{Al}_{2} \mathrm{O}_{3}$ や $\mathrm{CaS}$ の存在が確認されたことによつて $\mathrm{CaO}$ 坩堝壁が脱 硫に関与していることが明らかである。また $\mathrm{CaO}$ 坩佩 や $\mathrm{Al}_{2} \mathrm{O}_{3}$ 坩堝で $\mathrm{Al}$ の添加実験を行なつた場合, $\mathrm{Al}$ 添 加後の溶湯表面を観察したところ, $\mathrm{Al}_{2} \mathrm{O}_{3}$ 坩堝の場合生 成浮上した $\mathrm{Al}_{2} \mathrm{O}_{3}$ が湯面全体を覆う現象がみられたが， $\mathrm{CaO}$ 坩堝の場合生成 $\mathrm{Al}_{2} \mathrm{O}_{3}$ の浴面被覆は諗められず, 保持時間中湯面はきわめて清浄な状態であつた。これら の事実より本実験にみられた脱酸と同時に起こる著しい 脱硫作用は， $\mathrm{Al}$ 添加後 $\mathrm{CaO}$ 坩堝壁に付着した $\mathrm{Al}_{2} \mathrm{O}_{3}$ が，低融点の $3 \mathrm{CaO} \cdot \mathrm{Al}_{2} \mathrm{O}_{3}$ 系化合物として高塩基性の 脱硫能力を有する反応生成物層を坩融壁表面に生成した ことに起因するものではないかと推定されるに至つた。

\section{5 脱硫過程について}

一般にスラグーメタル間の脱硫反応, 脱硫速度は次式て 表わされている.

$[\mathrm{S}] \rightleftarrows(\mathrm{S})$

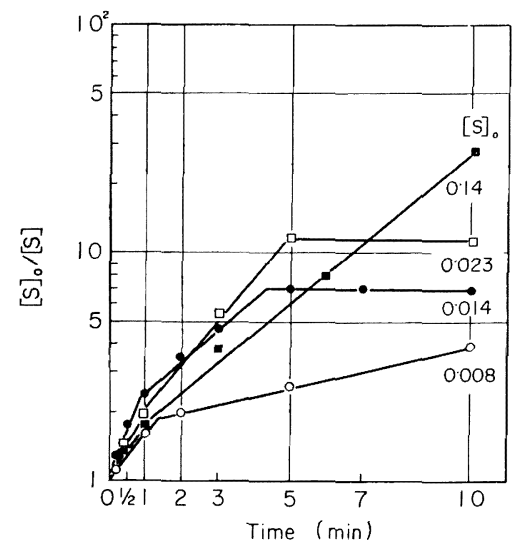

Fig. 21. Relation between $\log [\mathrm{S}]_{0} /[\mathrm{S}]$ and holding time after adding $0.2 \%$ aluminium.

$$
-d[\mathrm{~S}] d t=k_{m}[\mathrm{~S}]-k_{s}(\mathrm{~S})
$$

[S ] : 溶鉄中の流黄, (S ) : スラグ中の硫黄, $k_{m}: x$ タル $\rightarrow$ スグへの硫黄の移動係数, $k_{s}:$ スラグ $\rightarrow$ タル 一の硫黄の移動係数，本実験の場合，最初からスラグは 存在しないゆえ，反応の初期においてスラグーメタル中 への $\mathrm{S}$ の移動の項を無視すると，

$$
-d[\mathrm{~S}] / d t=k_{m}[\mathrm{~S}]
$$

で表わされ，これを時間に関して積分すると，

$$
\left.\log (\mathrm{S}]_{0} /[\mathrm{S}]\right)=k_{m} t
$$

となる.このように脱硫反応は溶鉄中の $\mathrm{S}$ の坩堝界面へ の移動拉よび坩佩界面での化学反応が律速となる場合一 次式で表わされ， [S ] o/ [S ]を求めて片対数グラフに表 示すると直線関係が成立するはずである，初期 $[S]_{0}$ 炎 変化した実験結果について整理したのが Fig. 21 であ る.この図で脱硫のほぼ $1 \mathrm{~min}$ 前後で折線となり,直線 関係が得られなかつた。これは上述の素過程が，本实験 における脱硫反応の律速段階となつていないことがうか がえる.すなわち川合氏ら11)の報告にもみられるごと く，溶鉄中の S 濃度が脱硫の進行にともなつて变化する ので, $\mathrm{CaO}$ 坩佩界面における反応生成物含有層中の $\mathrm{S}$ 濃度も变化することが考えられる，したがつて脱酸初期 に生成した $\mathrm{Al}_{2} \mathrm{O}_{3}$ の坩夙壁への付着と同時に脱硫に必要 な $3 \mathrm{CaO} \cdot \mathrm{Al}_{2} \mathrm{O}_{3}$ 采反応層の形成と成卡にともなう反応 生成物層を通じての $\mathrm{S}$ の移動律速で脱硫が進行したため ではないかと推察される。

\section{6 脱硫過程における [O]と［S]の関係}

溶鉄中の酸素量と脱硫作用とはきわめて密接な相関閔 係が存在するこ推定されたので，この関係定明確にする ために $\mathrm{Al}$ 添加後の各時点における $[\mathrm{O}]$ と [S ] の值 


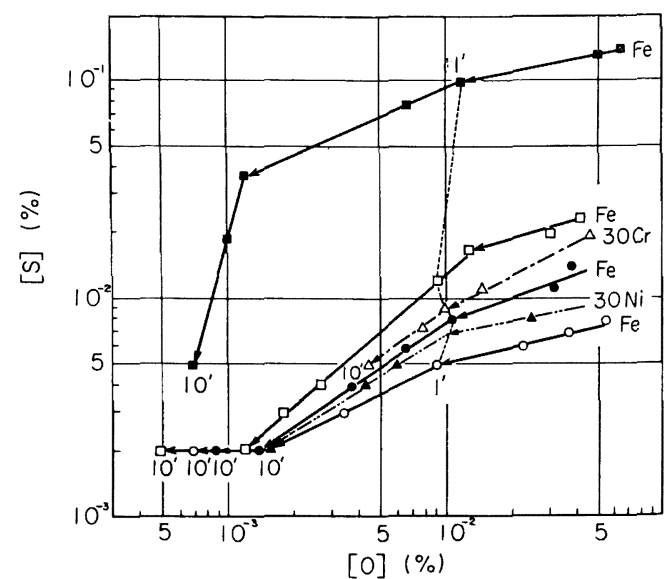

Fig. 22. Relation between the desulphurization and the deoxidation of liquid iron and liquid iron alloys after adding $0.2 \%$ aluminium. Dotted line: Isochronal line of $1 \mathrm{~min}$ after aluminium addition. $10^{\prime}: 10 \mathrm{~min}$ after aluminium addition.

を対数表示したのが Fig. 22 である. 初期 [O]。はほぼ $0.04 \sim 0.05 \%$ で初期 [S]。の異なる試料の脱酸脱硫過程 はいずれも 1 本の連続した線で示され， $0.2 \% \mathrm{Al}$ 添加

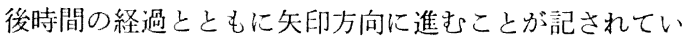
る. $[\mathrm{O}]=10^{-2}(\%)$ 附近に示した点線が $\mathrm{Al}$ 添加後 1 $\min$ の等時間線である.すなわち各脱酸脱硫過程とも $\mathrm{Al}$ 添加 $1 \mathrm{~min}$ 後で [O ] はいずれも 10-2\% 程度まで 減少していることがわかる.

この事実は $\mathrm{Al}$ 添加で生成与る $\mathrm{Al}_{2} \mathrm{O}_{3}$ の时堝壁への 付着が $[\mathrm{O}]=10^{-2} \%$ 程度でほぼ完了し,さらに $3 \mathrm{CaO}$. $\mathrm{Al}_{2} \mathrm{O}_{3}$ 系の生成による脱硫反応が促進されるが，同時に $[O]=10^{-2} \%$ 以下の還元性雲囲気にすることが有效で ある.脱硫作用は $[\mathrm{O}]=15 \mathrm{ppm}$ をで著しく進行し, [S] の最低值は $20 \mathrm{ppm}$ を示した. 比較的高硫黄を含む溶鉄 $[\mathrm{S}]_{0}=0.14 \%$ の場合, $[\mathrm{O}]=10^{-2} \%$ 程度の脱酸では脱 硫は不十分であり，十分な脱硫には $[\mathrm{O}]=10^{-3} \%$ 以下 の強還元性雾囲気が必要であることを示しており, 脱硫 に対する[O]の影響はきわめて大とい光る．初期 [O ] が低い場合は, $\mathrm{Al}$ 添加による $\mathrm{Al}_{2} \mathrm{O}_{3}$ の生成量は少なく, 坩佩壁に形成する脱硫に必要な $3 \mathrm{CaO} \cdot \mathrm{Al}_{2} \mathrm{O}_{3}$ 系反応生 成物層も少なくなるため, 脱硫は起こり難くなろうと考 えられるが，これらの点は更に検討を加えなければなら ない.また Fig. 4 に示したごとく， $\mathrm{Al}_{2} \mathrm{O}_{3}$ 坩堝を用い た $0.5 \%$ の $\mathrm{Ca}$ 添加実験では, $5 \mathrm{~min}$ 後に抒いて [O] $=23 \mathrm{ppm}$ まで脱陵され，かつ $[\mathrm{S}]=60 \mathrm{ppm}$ まで $25 \%$ の

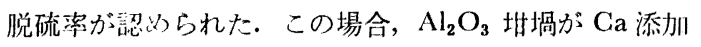

で還元され， $a_{\mathrm{CaO}}<1$ の $\mathrm{CaO} \cdot \mathrm{Al}_{2} \mathrm{O}_{3}$ 系の生成が脱硫作 用に寄与したものと考元られる. 以上のごとく $\mathrm{CaO}$ 坩 佩に $\mathrm{Al}$ 添加, $\mathrm{Al}_{2} \mathrm{O}_{3}$ 坩堝に $\mathrm{Ca}$ 添加などで観察された 脱硫作用は, いずれも $\mathrm{CaO} \cdot \mathrm{AlO}_{2}$ 系反店生成物の形成 がかなり重要な因子になつているものと推察された.

次にCをほとんど含ま好 $30 \% \mathrm{Cr}$ や 30\% Ni 系溶融鉄 合金の脱酸，脱硫に関しても図示してある. $\mathrm{Fe}-30 \% \mathrm{Ni}$ の場合，10 min で[ $\mathrm{S}]$ は 20ppm まで低下するが， Fe$30 \% \mathrm{Cr}$ の場合は [S] は 50ppm 以下に低減しなかつた。 後者の場合 $e_{\mathrm{S}}^{(\mathrm{Cr})}<0$ であることとともに脱酸が十分でな いた的に脱硫も進行しなかつたものとみなされる.

\section{5. 結言}

$\mathrm{CaO}$ 坩堝による溶鉄または溶融鉄合 金の鼠拌浴に対

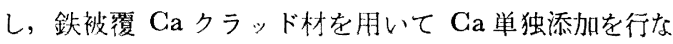
い, その添加量, 坩堝材質などによる脱酸過程を調べ, また $\mathrm{Al}$ によ脱硫作用を検討した絬果，次のことが明 らかとなつた。

（1）溶鉄の Ca 脱酸過程に求よぼす坦堝材質の影響 を調べたところ， $\mathrm{MgO}, \mathrm{CaO}, \mathrm{Al}_{2} \mathrm{O}_{3}$ の順に脱酸速度 は大となるとともに脱酸限は低下を示した. $\mathrm{MgO}$ や $\mathrm{Al}_{2} \mathrm{O}_{3}$ 坩堝を使用した場合, 坩凨壁の $\mathrm{Ca}$ による還元作 用を無視するここのできないことが判明した．Ca の添 加量を増加すると到達酸素值は低くなり, 脱酸速度は大 となるが Ca の有効作用効率は低下する.

(2) $\mathrm{CaO}$ 坩堝溶解の際, $\mathrm{Ca}$ 脱酸で尘成する介在物 組成は, $\mathrm{CaO} 20 \sim 60 \%, \quad \mathrm{FeO} 80 \sim 40 \%$ の $\mathrm{CaO}-\mathrm{FeO}$ 系であり, 脱酸後 $5 \mathrm{~min}$ 前後まで介在物の成長が涊め られた。

（3） Ca の脱酸過程はみかけ上溶鉄では 3 段階，溶 鉄より $\mathrm{Ca}$ の溶解度の大きい $\mathrm{Fe}-\mathrm{Ni}$ 系では 4 段階, 溶 解度の小さい $\mathrm{Fe}-\mathrm{Cr}$ 系では 2 段階に分けられる。 その 程度に大小はあるがすべて次の 4 段階を経る. Stage 1： $\mathrm{Ca}$ 気泡に上る脱酸, Stage II $-\mathrm{a}$ ：溶湯表面で $\mathrm{Ca}$ 蒸気 層形成による脱酸 (Ni 系溶鉄の場合), Stage II - b : 脱 酸生成物の系外への分蜼, Stage III : 定常状態

（4）溶鉄中 $\mathrm{Ca}$ の溶解度は本実験の場合， $\mathrm{Ca}=0 \cdot 024$ $\%$ \%見積られ， $\mathrm{Ca}$ 脱酸のみかけ上の平衡值として $K^{\prime}{ }_{\mathrm{Ca}}$ $=[\% \mathrm{Ca}][\% \mathrm{O}]=2 \cdot 16 \times 10^{-6}$, および平衡定数として $K_{\mathrm{Ca}}=5 \cdot 9 \times 10^{-9}$ の値が得られた.

（5） $\mathrm{CaO}$ 坩佩による溶鉄に対し $\mathrm{Al}$ 添加でみられ た同㭙脱酸脱硫作用は, $\mathrm{CaO}$ 坩城壁に $3 \mathrm{CaO} \cdot \mathrm{Al}_{2} \mathrm{O}_{3}$ の ごとき高塩基性の反応生成物層が形成されることによる ものと推定された。この㮔の脱硫反応は溶鉄中の酸素量 と密接な関係在有し, [O] が 10-2\% 以下に脱酸が進行 
するにつれて硫黄の顕著な減少が梁められた。

本実験を遂行するにあたり， $\mathrm{CaO}$ 坩堝の作製に協力 された当研究室佐藤敬博士に厚く御礼申し上げる．また 分析にご尽力下さつた本所武山主郎满師を初めとする其 通分析室の関係各位，X線回折をた EPMA の測定と同 定に便宜を計つて下さつた本所共通X線室の関係各位と 東北大学工学部渡辺融助教授に深く感謝の意を表するし だいである.

\section{交献}

1）小林三郎，大森康男，三本木貢治：鉄と鋼，56 (1970)8, p. 998

2 ）宮下芳雄，西川勝彦：鉄と鋼，57(1971)13, p. 1969

3) D. L. Sponseller and R. A. Flinn: Trans.
AIME, 230(1964)6, p. 876

4 ) 草川隆次, 田川寿俊, 神尾莌: 鉄と鋼, 58 (1972) 11, s. 378

5 ) $W . A$. Fischer and $T$. Cohnen: Arch. Eisenhüttenw., 21 (1950)11/12, p. 355

6 ) $W . A$. Fischer and $H$. Engelbrecht: Stahl u. Eisen, 75(1955) 2, p. 70

7 ) 吉井周雄, 島中和俊：鉄と鋼，43(1957)8, p.807

8 ) A. M. SAmarin: (川合, 大谷訳) 鋼の脱酸の物理 化学的原理, (1964)， p. 65[日本鉄鋼協会]

9) 音谷登平, 形浦安治: 鉄々鋼, 57(1971) 12, p. 1753

10）学振第 19 委員会編: 製鋼反応の推奖平衡值, (1968)，p、56 [日刊工業新聞社]

11）川合保治，森 克巳，三宮好史：鉄々鋼，61 (1975) 1, p. 29 